3 The adequacy of Victoria's protected areas for conserving its forest-dependent fauna 4

5 Chris Taylor ${ }^{1}$ and David B. Lindenmayer ${ }^{1,2}$

6

$7 \quad{ }^{1}$ Fenner School of Environment \& Society, The Australian National University, Canberra, $8 \quad$ ACT, 2601

9

$10 \quad{ }^{2}$ Threatened Species Recovery Hub, National Environmental Science Program, Fenner

11 School of Environment \& Society, The Australian National University, Canberra, ACT, 2601

12

13 Corresponding author

14 david.lindenmayer@,anu.edu.au; Tel 0261250654

15 Fenner School of Environment \& Society, The Australian National University, 141 Linnaeus

16 Way, Acton ACT 2601.

17

18 Running head: Vegetation classes, reserves and disturbance

19

\title{
20 ACKNOWLEDGEMENTS
}

21 The Authors wish to acknowledge the 38 Koori First Nation Clans of Victoria, upon whose respective lands this study was conducted and upon which their Sovereignty was never ceded.

23 We wish to acknowledge their Elders past, present and emerging. Claire Shepherd assisted in 24 editorial and other aspects of production of this paper. 


\section{ABSTRACT}

27 Networks of protected areas are a key component of efforts to conserve biodiversity. However, there are concerns about an uncritical focus on the percentage area of reserves without an assessment of how well formal reserves are actually protecting biodiversity. We completed a spatial analysis of the formal reserve system in the Australian state of Victoria. We quantified how well the reserve system captured a crude surrogate for vegetation communities (viz: Ecological Vegetation Classes) as well as distribution models for an array of threatened forest-dependent species. We found evidence of a high degree of overlap between areas subject to intensive forestry (clearcutting) operations and the modelled distribution of a suite of forest dependent species. A key outcome of our study was that areas around sites subject to past logging as well as new areas proposed for logging under the Timber Release Plan in Victoria had significantly higher values for threatened forest dependent species (as determined by habitat distribution models) than areas that had not been logged. We found significant differences in the spatial characteristics of the dedicated reserve systems and informal protected area networks, with the latter featuring much of its area close to a tenure boundary where logging occurs. Our empirical analyses demonstrating the impacts of ongoing logging operations on areas with high environmental suitability for threatened species has important implications. In particular, the current reserve system is inadequate for a suite of forest-dependent taxa, including Critically Endangered Leadbeater's Possum (Gymnobelideus leadbeateri) and the vulnerable Greater Glider (Petauroides volans). This suggests a high degree of conflict between areas of high value for conservation and areas targeted for wood production.

Key words: Protected areas, disturbance, logging, wet eucalypt forests, threatened species

\section{INTRODUCTION}


Many studies have highlighted the rapid decline of the world's biodiversity (e.g. Maxwell et al. 2016; Ceballos et al. 2017; IPBES 2019). Networks of protected areas are a key component of efforts to conserve biodiversity. For example, it has been estimated that approximately $25 \%$ of the world's bird biota has been saved from extinction due to conservation reserves (Rodrigues \& Brooks 2007). Under key initiatives such as the Aichi targets (among others), there is a concerted push to expand the protected area to $17 \%$ of the world's terrestrial surface area, although some scientists argue much higher levels of protection - up to $50 \%$ or more - are both needed and feasible for biodiversity protection (Wilson 2016; Dinerstein et al. 2017). While there has been an increase in the extent of protected areas globally, both on land and in the oceans, there have been concerns expressed about an uncritical focus on the percentage area of reserves without an assessment of how well formal reserves are actually protecting biodiversity (Visconti et al. 2019). Indeed, Visconti et al. (2019) highlighted issues with the 'simple use of percentage targets' which have led to perverse outcomes that incentivise the creation of protected areas that have limited conservation and biodiversity value. This problem has long been recognized, for example, under the broad rubric of the so-called "worthless lands hypothesis", in which protected areas are established in those places without value for other human exploits like agriculture, forestry, mining or urban development (Pressey et al. 1993; Lindenmayer \& Burgman 2005; Taylor et al. 2017; Venter et al. 2018). In an effort to counter problems with the bias in reserve systems, the notion of the Comprehensive, Adequate and Representative principles have long been proposed to guide the design of networks of protected areas (JANIS 1997; Commonwealth of Australia 1999; NRMCC 2005). That is, effective reserves should be Comprehensive, Adequate and Representative (CAR) in an attempt to protect the full range of biodiversity in a region. 
from species (and their associated genetic variation) to communities and ecosystems.

Adequacy relates to the need to support populations that are viable in the long term.

Representativeness means that a reserve system should sample species, vegetation types, communities and ecosystems from throughout their geographic ranges (Margules \& Pressey 2000; Lindenmayer \& Burgman 2005).

In Australia there has been some expansion of the reserve system in the past few decades, and levels of comprehensiveness have been enhanced (Barr et al. 2016).

Nevertheless, Watson et al. (2011) and Venter et al. (2018) found that many of Australia's threatened species either do not occur in reserves or have distributions that fall largely outside of the protected areas network. In forested ecosystems, CAR principles underpin the Regional Forest Agreements that are designed to balance conservation objectives with access to timber and pulpwood for forest industries (DEWHA 2009; DAWR 2017). However, detailed analyses show that the current reserve systems in some RFA areas do not meet CAR principles, particularly in terms of reserve adequacy and the need for protected areas to support viable populations of threatened taxa (Todd et al. 2016; Taylor et al. 2017). This problem has more broadly been identified globally, where the Intergovernmental SciencePolicy Platform on Biodiversity and Ecosystem Services report stated that protected areas only partly cover important sites for biodiversity. Therefore, reserve systems are not yet fully ecologically representative and effectively managed (IPBES 2019).

One of the major challenges in designing and establishing reserve systems is that it is simply not possible to document all biodiversity (Gaston \& Spicer 2004). Strategic reserve design is therefore based on employing biodiversity surrogates (sensu Lindenmayer et al. $2015 b$ ) that are thought to indicate the distribution and or abundance of unmeasured species or other elements of biodiversity (Caro 2010). In the investigation reported here, we sought to assess the extent to which the current reserve system in the Australian State of Victoria 
captures a suite of forest-dependent threatened species (as determined by developing species distribution models (Elith \& Leathwick 2009) for those taxa) across multiple Ecological Vegetation Class (hereafter termed EVCs) Groups. An EVC Group can be loosely defined as one or more vegetation communities with broadly similar floristic, structural, habitat and environmental characteristics where broadly similar ecological processes occur (DELWP 2019a). We also sought to determine levels of human disturbance (primarily logging) within particular EVCs, especially the Wet and Damp Forest EVC Group.

We based this study on three simple questions:

- What is the level of representation of different EVCs in the reserve system in Victoria?

- How well are different threatened species represented in the reserve system?

- What are the spatial configurations of different protected area types across the more productive areas, such as the Wet and Damp Forest EVC Group (where there is potential for large-scale timber and pulp extraction activities such as industrial logging),

117 productive areas are spatially concentrated, with less productive land more likely to be placed

118 in reserves. This been the case for Victoria, where advocates for native forest logging

119 industry argue that 94 per cent of Victoria's forests on public land are protected in parks, reserves or land unsuitable for logging, thereby justifying logging within the remaining 6 per cent (VicForests 2019c). However, environmental values are not evenly distributed across

122 forest types. Similar to previous work, albeit at a larger (national) scale (see Watson et al.

123 2011; Kearney et al. 2018.), we predicted that many threatened species would not be well conserved by the current reserve system in Victoria. Reserves throughout industrially 
125 productive areas can be small and fragmented (Venter et al. 2018). Furthermore, these

126 networks of smaller and fragmented reserves can be exposed to edge effects resulting from

127 adjoining industrial logging operations (Parry 1997; Lindenmayer and Franklin 2002). In this

128 context, the spatial configuration of protected areas is critical to their effectiveness.

129 The work outlined in this article is a spatial assessment of the current protected area

130 network in Victoria, particularly in regard to the level of protection across EVC groups. It

131 also explores the intersection between the distribution of threatened forest-dependent species

132 and where logging is concentrated. This kind of information is vital for helping to identify

133 areas that should be prioritised for subsequent addition to the dedicated reserve network and

134 is especially relevant in Victoria where recent policies have been implemented to modernize

135 Regional Forest Agreements (RFAs) (DELWP 2019c).

136 METHODS

137 We assessed land cover patterns in Victoria by land tenure and Ecological Vegetation Class

138 (EVC) Groups. Using the program Zonation (Moilanen et al. 2005), we then quantified the

139 modelled distributions of threatened species distributions using Habitat Distribution Models

140 (HDMs) in relation to land tenure, EVC Groups and areas where logging is concentrated.

$141 \quad$ Land Tenure Analysis

142 We used spatial data from the Australian Collaborative Land Use and Management

143 Program (ACLUMP) to inform our land tenure analysis (ABARES 2011). ACLUMP is a

144 nationally agreed classification system for land use information. It aims to provide a

145 monitoring and evaluation framework, consisting of a three tiered hierarchical structure. The

146 primary tier consists of six classes, which include conservation areas, production from natural

147 environments, dryland agriculture, irrigated agriculture, intensive use and water. The

148 secondary and tertiary classes cover sub-categories, such as specific conservation reserve

149 classifications. ACLUMP uses a spatial reallocation of aggregated data modelling, which 
150 included Australian Bureau of Statistics (ABS) census data from which it is partly derived. It

151 also uses the Collaborative Australian Protected Areas Database (CAPAD) and catchment

152 scale land use mapping for Australia. However, limitations of ACLUMP include the absence

153 of land use change over a given period of time, the coarse scale of the datasets $(1: 2,000,000)$,

154 and relative standard errors across agricultural land use (ABARES 2011). We cross-validated

155 the ACLUMP dataset with regionally-specific land use maps and vegetation extent obtained

156 through satellite data, along with Forest Management Zones and CAPAD protected area

157 boundaries (Claverie et al. 2018). We corrected errors in spatial data where we detected them.

158 The CAR reserve system

159 Under the National Forest Policy Statement (Commonwealth of Australia 1992), Australian

160 federal, state and territory governments agreed to a Comprehensive, Adequate and

161 Representative (CAR) reserve system, which was intended to protect $15 \%$ of the pre-1750

162 distribution of each forest ecosystem (JANIS 1997). It was to consist of dedicated reserves,

163 informal Reserves and other areas on public land protected by prescription. It also included

164 areas of private land by agreement with private landholders. The CAR reserve system formed

165 an important part of the Regional Forest Agreements (RFAs), which were signed between the

166 Australian federal Government and the individual state governments (Department of

167 Agriculture 2015).

168 Under the dedicated reserve system, protected areas were to be assigned under

169 equivalent categories to those defined by the IUCN Commission for National Parks and

170 Protected Areas (CES 2018). These consist of strict nature reserves (Ia), wilderness areas

171 (Ib), national parks (II), natural monuments or features (III), habitat or species management

172 areas (IV), protected landscapes/ seascapes (V) and protected areas with limited use of

173 natural resources (VI). The IUCN defines a protected area as: " $a$ clearly defined

174 geographical space, recognised, dedicated and managed, through legal or other effective 
means, to achieve the long-term conservation of nature with associated ecosystem services and cultural values" (Dudley et al. 2013). In Australia, the Joint ANZECC/MCFFA NFPS

177 Implementation Sub-Committee (JANIS) considered that a dedicated reserve to be an area secured under parliamentary action, either by federal or state/territory governments (JANIS 1997). In Victoria, most dedicated reserves are gazetted under the National Parks Act 1975. The CAR reserve system also includes areas outside of dedicated reserves, which comprise informal protected areas and areas protected under prescription. These informal protected areas are under state forest land tenure and were established under approved forest management plans throughout Victoria and logging prescriptions (DNRE 1998; DEPI 2014a). They were excluded from the dedicated reserve system because the Victorian government did not consider it possible nor practicable to include them into the dedicated reserve network (JANIS 1997). These areas were designated Special Protection Zones (SPZs) and Code of Forest Practices (CFP) Exclusions (DNRE 1998). SPZs were intended to complement the conservation reserve network and to help capture representative samples of vegetation communities, old growth forest, and locations supporting threatened fauna.

190 Logging is currently excluded from these areas, but they are not considered secure, meaning that they are not gazetted under legislation (JANIS 1997). The remaining parts of the CAR reserve system were designated as exclusions areas under the Code of Forest Practices for Timber Production, the regulatory document to which logging in native forests must comply

194 (DEPI 2014a). These exclusion areas consisted of slopes exceeding 30 degrees and 195 streamside buffers, consisting mostly of 40 metres (DELWP 2019b). We used the Collaborative Australian Protected Areas Database (CAPAD) to inform

197 our analysis of the protected area network, along with forest management zones describing 198 areas outside of the dedicated reserve network (DEE 2016; DELWP 2019b). We described 199 the dedicated reserve network as such in our analysis. For SPZs and Code of Forest Practice 
200 Exclusion areas outside the dedicated reserve network, we described these as informally

201 protected areas in our analysis.

\section{Boundary edge analysis}

203 We explored aspects of the spatial configuration of reserves by conducting a Euclidean

204 distance analysis (Joppa et al. 2008; Crooks et al. 2017) from random points inside dedicated

205 and informal protected areas to their respective tenure boundaries. We generated a Euclidean

206 distance raster in ArcGIS with each internal 50x50m cell occurring within a protected area

207 featuring a distance value in metres from its nearest boundary. We generated a random

208 selection of 20,000 points across the dedicated reserve and informal protected area network

209 and assigned each point with its respective distance from the nearest land tenure boundary.

210 We categorized sample points under their respective protected area type and EVC Group. We

211 used a Tukey's HSD to test for statistical significance between protected area types with

212 regard to the respective distances of points to an edge.

\section{Forest where logging is permitted}

214 Public land outside the CAR reserve system in Victoria is where logging and other industrial

215 activities are permitted under the Code of Forest Practices for Timber Production (DEPI

216 2014a) and other management standards (DEPI 2014b). Included in the state forest land

217 tenure, this area covers three zones: 1) General Management Zone (GMZ); 2) Special

218 Management Zone (SMZ); and 3) historical reserves (DNRE 1998). General Management

219 Zones are managed for a range of uses, but industrial logging is prioritised. Special

220 Management Zones include areas of high landscape value where logging practices may be

221 modified in an attempt to conserve some of the values. It does not constitute an informal

222 protected area. Logging is also permitted in historic reserves, whereby specific sites of

223 historic importance are to be excluded, but logging can occur around them (DNRE 1998).

224 Where the Code of Practice for Timber Production prohibits logging in GMZs and SMZs, 
these are designated as Code of Forest Practice Exclusion areas and form part of the informal protected area network (DEPI 2014a).

For our analysis, we used forest management zone data to identify areas of GMZ and SMZ (DELWP 2019b). This was a simplified dataset that did not include Code of Forest Practice Exclusion zones. To identify these, we used a digital elevation model (DEM) to identify slopes greater than 30 degrees and to identify water courses where buffers would have logging operations excluded (EROS 2019).

\section{EVC Groups}

233 For the analysis of native forest areas and other vegetation groups, we used Ecological

234 Vegetation Class (EVC) Group (DELWP 2019d). The EVC Groups dataset was developed by 235 the Victorian Government to categorize the landscape into native woody cover, native grassy cover and native wetland cover, together with probability ratings for a given area to support a particular kind of native vegetation cover. The EVC Groups dataset is a combination of a number of spatial datasets such as tree cover, rainfall and temperature together with timeseries LANDSAT imagery and ground-truthed site data. The data set is designed for use at a

240 large scale $(1: 25,000$ to 1:100,000). We used the EVC Group category, which covered 20 vegetation broad native vegetation types, including Wet and Damp Forests, Rainforests, Dry forests, and Mallee EVC Groups. We applied this dataset across all land tenures throughout

243 Victoria.

\section{Logging data}

245 We used historical logging datasets and proposed logging planned under the 2019 Timber

246 Release Plan (TRP) (VicForests 2019b), to analyze the EVC Groups targeted by commercial

247 logging activities (DELWP 2019d). The logging history dataset consisted of LASTLOG 25, 248 which represents the spatial extent of the most recent logging activity recorded for any given 249 area in state forest (DJPR 2019). This data set stores details of the last time an area was 
250 known to be logged, the species logged, and the logging method employed. It represents a consecutive overlay of all logging seasons, from 1961-62 season to the logging season 20162017. The TRP details the location and the gross area of planned logging, and which is to be undertaken by the Victorian Government owned logging business, VicForests. A TRP covers logging for a period of up to 5 years (VicForests 2019a).

\section{Habitat Distribution Models}

We used a subset of unpublished habitat distribution models (HDMs) for 70 species in our analysis (Arthur Rylah Institute unpublished data). These HDMs were developed for, and used by, the Victorian Environment Assessment Council (VEAC) in its assessment of biodiversity values across Victoria. That study identified over 70 species as being solely dependent on native forests for habitat (VEAC 2017) (see Table S1). The species not included were those not dependent on native forests or those found to inhabit other habitat types in addition to native forests (VEAC 2017).

The habitat distribution models were spatially modelled on the environmental

264 characteristics favoured by a given species. Typical environmental attributes included elevation, rainfall, soil type, aspect and slope (VEAC 2017). The analysis further incorporated species-specific modifications, such as tree age for the critically endangered

267 Leadbeater's Possum (Gymnobelideus leadbeateri). We used these species habitat distribution models in our spatial prioritisation analysis. The spatial scale of the habitat

269 distribution models consists of a raster grid cell of $75 \times 75 \mathrm{~m}$.

\section{Zonation}

271 We used the program Zonation (ver. 4.0) (Moilanen et al. 2005) to identify priority areas across all native forest areas throughout Victoria. Zonation produces a hierarchical ranking of multiple species habitat distribution models over the landscape using a series of algorithms.

274 Zonation's 'core area' algorithm was used to allocate a conservation value to each $75 \times 75 \mathrm{~m}$ 
cell across the landscape based on: (1) the relative suitability of a cell for each species; (2) the weights assigned to species (see below); and (3) the proportion of the remaining habitat for each species that the cell represents. In this way, Zonation ranked each cell in the landscape according to how 'irreplaceable' it was for achieving representation of the suitable habitat for each species. In the process of analysis, output cells were proportionately ranked between zero and one. Zonation first removed the least valuable cells from the landscape. The more valuable cells (indicating core areas for species distributions) were removed last in the analysis (Moilanen et al 2014). When a cell was removed, the value across remaining cells increased (Moilanen and Wintle 2006). Areas that contained habitat for rarer species was ranked as highly irreplaceable because habitat for those species was only available in a few or no other place in the landscape.

We produced a series of maps to reflect different habitat distribution model weightings based on the threatened status of the respective species. We allocated weights for the 70 species in relation to their conservation status according to the IUCN Red List, EPBC Act 1999 and the Victorian Flora and Fauna Guarantee Act 1988. As there was no best way to weight features, we compared three numerical species weighting scenarios: (1) equal weight (the Zonation default), (2) linear weight, and (3) log weight (Table 1) (Fiorella et al. 2010). The output for the Zonation analysis consisted of a raster grid dataset with each cell across the landscape ranked from zero to one. The highest values cells represented the most suitable

294 habitat areas for the greatest number of species.

We measured the distribution of Zonation priority areas representing suitable habitat for each species within different land tenure categories and forest management zones. We

297 generated a series of 20,000 random points across the EVC Groups throughout Victoria in 298 ArcGIS. Each point contained the Zonation priority value representing suitable habitat 299 distribution for each species in accordance with their respective threatened status weight. The 
300 points were grouped into their respective land use tenures. We used a Tukey's HSD to test for

301 the statistical significance of Zonation Values between land tenures for selected EVC Groups,

302 as well as areas around previously logged sites and areas scheduled for logging under the

303 TRP. Statistical significance was noted at $\mathrm{P}<0.05$.

\section{RESULTS}

\section{Area analysis}

306 The area of Victoria is nearly 23 million hectares (Table 2). The largest land tenure is

307 agriculture, consisting of 13 million hectares or $58 \%$ of the State's land area. The next largest

308 are conservation reserves and other protected areas, consisting of 4.4 million hectares or 19\%

309 of the state's area. The third largest land tenure area consists of state forests, comprising 14\%

310 of the Victoria's land area. Around 1.7 million hectares of state forests is designated under

311 GMZ and SMZ, where logging is permitted. This equates to $8 \%$ of the state's total land area.

312 The dedicated reserve network consists of several large protected areas, with two

313 exceeding 600,000 hectares in size, those being the Murray Sunset and Alpine National Parks

314 (Fig. 1). There are multiple smaller dedicated reserves in the form of 'conservation reserves',

315 such as the 600 hectare Mount Bullfight Conservation Reserve and 47 hectare Seven Acre

316 Rock Natural and Scenic Features Reserve (LCC 1994). The informal protected area network

317 consists of small and fragmented areas located outside the dedicated reserve network. It

318 covers a total area of 1.13 million hectares mostly throughout the eastern half of the state.

319 The land area where logging is permitted is also a fragmented land tenure network, located in

320 between, and adjoining the dedicated reserve and informal protected area networks.

322 Group across the semi-arid areas in the Victoria's north west to the Rainforest EVC Group in

323 the cool temperate south east of the State (Fig. 2) (see Appendix S13). The largest areas are

324 dominated by the Dry Forests EVC Group, covering an area of 2.7 million hectares or $26 \%$ of 
the total EVC Group area. The next largest is the Mallee EVC Group, encompassing 1.54 million hectares or $15 \%$ of the state's native vegetation classified under the EVC Groups. The next largest is the Wet and Damp Forest EVC Group, which covers 1.35 million hectares (Fig. 3).

The land use categorization of the EVC Groups are variable, with some EVC Groups afforded high levels of protection in the dedicated reserve system. The Mallee EVC Group has 1.12 million hectares or $73 \%$ of its total area within the dedicated reserve system (Fig. 3). The Dry Forest EVC Group features the largest area allocated to state forest Land tenure, consisting of 1.3 million hectares or $47 \%$ of its total area. The next largest is the Wet and Damp Forest EVC Group, with 799,000 hectares in state sorests, equating to 59\% of its total area. It has the largest percentage of its area allocated to state forests of all the EVC Groups.

\section{Protected area boundary analysis}

We found that the dedicated reserve network performed better than informal protected areas in terms of the area and shape of each dedicated reserve (Fig. 4). For the Wet and Damp Forests EVC Group, the median distance for a random point inside the dedicated reserve network to a boundary was $1,700 \mathrm{~m}$. In comparison the median distance to a boundary for informal protected areas was only 71 metres. We found a statistically significant difference in distance to a boundary between dedicated reserves and informal protected areas across the Wet and Damp Forest EVC Group (Table 3). For the Dry Forest EVC Group, the median distance was 1,232 $\mathrm{m}$ for a random point inside the dedicated reserve network to a boundary. The equivalent median distance across the informal protected area network was 180 metres. We found that the Mallee EVC Group scored higher than all other EVC Groups, with a median distance to its respective dedicated reserve boundary of $5,209 \mathrm{~m}$.

Across all EVC Groups, we found that the dedicated reserve network overall performed better than informal protected areas, with the median distance for a random point inside the 
350 dedicated protected area network to a boundary being $1,756 \mathrm{~m}$. In comparison, the median

351 distance to a boundary for informal protected areas was only 150 metres. The other park

352 tenure featured a median distance to its respective tenure boundary of 300 metres (Fig. S1).

353 These differences were significant for the sampled EVC Groups as well as the overall EVC

354 Group area (Table 3).

355 EVC Groups and logging

356 The Wet and Damp Forest EVC Group has been heavily targeted for logging (Fig. 5; Table

357 S3). Nearly 260,000 hectares or $19 \%$ of this EVC Group has been subject to logging, with

358 around $74 \%$ of this logged using clearcutting. The EVC Group featuring the least area logged

359 is Mallee, with only 4,617 hectares or $0.3 \%$ of its area logged (Table S3).

360 Zonation habitat distribution prioritisation

361 Using Zonation analysis, we found the most important areas for forest-dependent threatened

362 species and which supported the greatest amount of suitable habitat occurred in areas

363 designated for logging, with a median equal weight Zonation value of 0.86 (Figs. 6 and 7).

364 The median Zonation values for our linear and log weight analysis were 0.82 and 0.83 ,

365 respectively (Figs. S2, S3, S5 and, S6). This means that the median cells within land tenure

366 where logging is permitted across state forest were ranked above $82-86 \%$ of remaining cells

367 across other forested land tenure in the analysis. The next highest scoring land tenure were

368 the informal protected areas, with a median Zonation values of $0.80,0.79$ and 0.84 for the

369 equal, linear and log weights, respectively (Figs. S4, S5 and S6). Dedicated reserves achieved

370 median Zonation values of $0.71,0.70$ and 0.72 for the equal, linear and log weights,

371 respectively (Figs. S4, S5 and S6). The lowest median Zonation value for all weights was for

372 'other state forest', which is mostly located within the Mallee EVC Group (Figs. S4, S5 and

373 S6). The differences in the range of Zonation values were statistically significant between 
374 dedicated reserves, informal protected areas and areas where logging is permitted (Table 4, 375 S4 and S5).

The Wet and Damp Forest EVC Group featured one of the highest median Zonation 377 equal weighted scores in our analysis of 0.90 (Figs. S7, S8 and S9). For specific areas of this

378 EVC Group around previously logged sites and areas scheduled for logging under the TRP 3792019 , we found a Zonation equal weight value of 0.93 and 0.94 , respectively (Fig. 8). Similar 380 trends were noted for the linear and log weights (Figs. S10 and S11). Statistically significant 381 higher ranges in Zonation values were noted for the areas around previously logged sites and

382 areas scheduled for logging compared with areas with no logging or not scheduled for

383 logging (Tables 5 and S6). For the Dry Forest EVC Group, the median Zonation equal weight

384 score was 0.76 . For specific areas of this EVC Group around previously logged sites, we also 385 found a similar median Zonation equal weight value of 0.76 , but a higher median of 0.87 for

386 areas scheduled for logging under the TRP 2019. Comparably, the Mallee EVC Group

387 featured the lowest median equal weighted Zonation score of 0.1.

\section{DISCUSSION}

389 Assessing the biodiversity value of protected areas is critical to determining their

390 effectiveness or otherwise. It is also crucial for determining priority areas for additions to the

391 existing protected area network. We completed a spatial analysis of the dedicated reserve

392 system in Victoria and its intersection with distribution models for an array of threatened

393 forest-dependent species. As expected, we found that some EVC Groups were poorly

394 protected and others, such as the Wet and Damp Forest EVC Group, having been subject to

395 extensive disturbance such as through clearfell logging. Our analyses also revealed areas

396 previously targeted for logging and those proposed for logging under the recently released

397 Timber Release Plan (VicForests 2019a) in that EVC Group support forests of significantly

398 higher value for threatened forest-dependent species than unallocated forest for logging in the 
same EVC Group. We further discuss these findings in the remainder of this paper and conclude with some commentary on how to enhance the conservation of forest biodiversity and EVC Groups that have been subject to high levels of logging-generated disturbance.

\section{EVC Groups, levels of protection and human disturbance from logging}

403 Our analyses revealed a distinct bias in the reserve system, with EVC Groups on more

404 productive and economically valuable land afforded lower levels of protection (Fig. 3). This is consistent with previous, broader national-level analyses (e.g. Venter et al. 2018) as well as work in other parts of the world and globally (Scott \& Tear 2007).

We found that the dedicated reserve system and the informal protected area network are significantly different, with the former consisting of comparatively larger protected areas and the latter consisting of a small and fragmented network. Most of the informal protected area is close to a land tenure edge. Where these fragmented informal protected areas directly

411 adjoin industrial logging operations, they may be negatively impacted, especially if the

412 logging occurs along multiple boundaries. Distinct edges or boundaries are created between 413 clearcut and unlogged areas, and where profound modifications of biological and physical 414 conditions can occur (Lindenmayer \& Franklin 2002). Edge effects can include significant 415 microclimatic changes, such as increased temperature and decreased humidity (Parry 1997).

416 Where the median distance for informal protected areas is as low as 71 metres for the Wet 417 and Damp Forests EVC Group, this network may be subjected to marked edge impacts. We found evidence of a high degree of overlap between areas subject to industrial

419 logging operations and the modelled distribution of a suite of forest dependent species.

420 Indeed, a key outcome of our study was that areas subject to past logging as well as new 421 areas proposed for logging under the Timber Release Plan in Victoria (VicForests 2019b) had 422 significantly higher values for threatened species (as determined by habitat distribution models) than areas that had not been logged (Figs. 7 and 8). This shows a high degree of 
conflict between areas of high value for conservation and areas targeted for wood production.

Such kinds of conflicts have been observed in forest estates globally (e.g. Lindenmayer \& Franklin 2002; Scott \& Tear 2007; Visconti et al. 2019). As a useful historical example of a similar outcome, work in south-eastern New South Wales showed that the highest populations of arboreal marsupials were concentrated in relatively small parts of the forest estate that also occurred in places with the highest soil fertility and were preferred areas for logging (Braithwaite et al. 1983; Braithwaite et al. 1988). Collectively, these findings indicate that high productivity areas for tree growth and wildlife habitat provision may also be those places most suited for wood production.

Our empirical analyses demonstrating the impacts of ongoing logging operations on areas with high environmental suitability for threatened species have several important implications. First, past analyses in the Central Highlands region has shown that the current reserve system is inadequate for a suite of forest-dependent taxa, including Critically Endangered Leadbeater's Possum and the vulnerable Greater Glider (Petauroides volans) (Todd et al. 2016; Taylor et al. 2017). Indeed, populations of both species are undergoing severe decline, including in reserves (Blair et al. 2018; Lindenmayer \& Sato 2018). This means that existing reserves are not adequate, and therefore do not meet one of the core

441 principles of a CAR protected area network. Second, off-reserve management is currently not 442 providing a sufficient complementary contribution to the reserve system for these species 443 (Lindenmayer et al. 2015a; Lindenmayer \& Sato 2018). This is important because ongoing 444 logging under the Timber Release Plan will only serve to further erode the suitability of off445 reserve areas for biodiversity, especially as such operations will be concentrated in areas with 446 significantly higher predicted values for forest-dependent threatened species than in forests 447 where logging is not occurring. Therefore, ongoing human disturbance generated by logging 448 will likely further exacerbate existing declines in threatened species. 
A third key implication of our analyses relates to recent attempts to modernize the

450 Regional Forest Agreements in Victoria (DELWP 2019c). A fundamental tenet of Regional

451 Forest Agreements is to ensure the conservation of forest biodiversity (Department of

452 Agriculture 2015). The information presented in this paper suggests that, as part of

453 modernizing RFAs, areas of the Wet and Damp EVC Group should be among those targeted

454 for addition to the existing dedicated protected area network to promote the conservation of 455 forest-dependent threatened species.

\section{Problems with area as a simple metric for assessing protected area effectiveness}

International benchmarks such as Aichi targets set objectives for the percentage of the

land surface or the ocean that should be reserved. However, several authors have highlighted the limitations of simple metrics based on percentage area (e.g. Visconti et al. 2019) in part because they fail to account for both the suitability for biodiversity of particular reserves and the viability of populations within such protected areas. In Victoria, forest industry advocates often argue that logging occurs in only a small part of the forest estate and that it will therefore have only limited impacts on other values (such as biodiversity conservation) (VicForests 2019c). Our analyses show, however, that not all areas of forest are created equal in terms of their value for forest-dependent species. For example, nearly $30 \%$ in area of the top $10 \%$ scoring forest in our analysis occurred on land available to logging (Table S7). concentrated in particular EVC Groups such as those with a high predicted value for a suite of threatened forest-dependent species. Logging operations therefore have a disproportionally higher impact relative to the size of the area within which they occur. Part of the problem with simplistic arguments about the crude size of the area subject to logging is that much of the area of forest in Victoria encompasses environments such as the Mallee EVC Group in 
north-western Victoria that are both well protected and were never targeted for logging in the

474 first place.

475

476

477

478

479

480

481

482

483

484

485

486

487

488

489

490

491

492

493

494

495

496

497

\section{REFERENCES}

ABARES (2011) Guidelines for land use mapping in Australia: principles, procedures and definitions. A technical handbook supporting the Australian Collaborative Land Use and Management Program . 4th Edition. Australian Government, Canberra.

Barr L.M., Watson J.E., Possingham H.P., Iwamura T. \& Fuller R.A. (2016) Progress in improving the protection of species and habitats in Australia. Biol. Conserv. 200, 184191.

Blair D., McBurney L. \& Lindenmayer D.B. (2018) Failing to conserve Leadbeater's Possum and its Mountain Ash forest habitat. Aust. Zool. 39, 443-448.

Braithwaite L.W., Binns D.L. \& Nowlan R.D. (1988) The distribution of arboreal marsupials in relation to forest types in the Eden (N.S.W.) woodchip concession area. Aust. Wildl. Res. 15, 363-373.

Braithwaite L.W., Dudzinski M.L. \& Turner J. (1983) Studies on the arboreal marsupial fauna of eucalypt forests being harvested for woodpulp and Eden, New South Wales. II. Relationships between the fauna density, richness and diversity and measured variables of the habitat. Aust. Wildl. Res. 10, 231-247.

Caro T. (2010) Conservation by Proxy. Indicator, Umbrella, Keystone, Flagship, and Other Surrogate Species. Island Press, Washington D.C.

Ceballos G., Ehrlich P.R. \& Dirzo R. (2017) Biological annihilation via the ongoing sixth mass extinction signaled by vertebrate population losses and declines. Proc. Natl. Acad. Sci. USA 114, E6089-E6096.

CES (2018) State of the Forests 2018 Report. Commissioner for Environmental Sustainability Victoria, Melbourne. 
498 Claverie M., Ju J., Masek J.G., et al. (2018) The Harmonized Landsat and Sentinel-2 surface reflectance data set. Remote Sens. Environ. 219, 145-161.

500 Commonwealth of Australia (1992) National Forest Policy Statement. Australian Government Publishing Service, Canberra.

502 Commonwealth of Australia (1999) Australian Guidelines for Establishing the National 503 Reserve System. (ed. by E. Australia). Environment Australia, Canberra. available from https://www.environment.gov.au/land/nrs/publications/australian-guidelinesestablishing-nrs.

Crooks, K.R., Burdett, C.L., Theobald, D.M., et al. (2017). Quantification of habitat fragmentation reveals extinction risk in terrestrial mammals. Proc. Natl. Acad. Sci. USA 114, 7635-7640.

DAWR (2017) Regional Forest Agreements. Australian Government Department of Agriculture and Water Resources, Canberra. Available from http://www.agriculture.gov.au/forestry/policies/rfa. Accessed 20 May 2019.

DEE (2016) Collaborative Australian Protected Area Database. Australian Government Department of the Environment and Energy, Canberra. Available from https://www.environment.gov.au/land/nrs/science/capad/2016. Accessed 29 April 2019.

DELWP (2019a) Bioregions and EVC benchmarks. Victorian Government Department of Accessed 20 May 2019.

DELWP (2019b) Forest Management Zones - Simplified View. Victorian Government 
https://discover.data.vic.gov.au/dataset/forest-management-zones-simplified-view. Accessed 30 April 2019.

DELWP (2019c) Modernising Victoria's regional forest agreements. Victorian Government Department of Environment, Land, Water and Planning, Melbourne. Available from https://www.forestsandreserves.vic.gov.au/forest-management/regional-forest-

DELWP (2019d) Native Vegetation - Modelled 2005 Ecological Vegetation Classes (with Bioregional Conservation Status). Victorian Government Department of

Department of Agriculture (2015) Regional Forest Agreements - an overview and history.

DEPI (2014b) Management Standards and Procedures for timber harvesting operations in

DEWHA (2009) The Australian Environment Act - Report of the Independent Review of the

DEPI (2014a) Code of Practice for Timber Production. Victorian Government Department of policies/rfa/rfa-overview-history.pdf.

Environment and Primary Industries, Melbourne.

545 Dinerstein E., Olson D., Joshi A., et al. (2017) An ecoregion-based approach to protecting half the terrestrial realm. BioScience 67, 535-545. 
DJPR (2019) Logging history overlay of most recent harvesting activities. Victorian Government Department of Jobs, Precincts and Regions, Melbourne. Available from https://discover.data.vic.gov.au/dataset/logging-history-overlay-of-most-recentharvesting-activities. Accessed 29 April 2019.

DNRE (1998) Forest Management Plan for the Central Highlands. Victorian Government Department of Natural Resources and Environment, Melbourne.

Dudley N., Sahadie P. \& Stolton S., P. Shadie and N. Dudley (2013). IUCN WCPA Best Practice Guidance on (Eds) (2013) Guidelines for Applying Protected Area Management Categories including IUCN WCPA best practice guidance on recognising protected areas and assigning management categories and governance types. IUCN, Gland, Switzerland:.

Elith J. \& Leathwick J.R. (2009) Species distribution models: ecological explanation and prediction across space and time. Ann. Rev. Ecol. Evol. S. 40, 677-697.

EROS (2019) ASTER Eastern Victoria image retrieved from https://asterweb.jpl.nasa.gov/gdem.asp. Website maintained by the NASA EOSDIS Land Processes Distributed Active Archive Center (LP DAAC) at the USGS Earth Resources Observation and Science (EROS) Center, Sioux Falls, South Dakota.

Fiorella K., Cameron A., Sechrest W., Winfree R. \& Kremen C. (2010) Methodological considerations in reserve system selection: A case study of Malagasy lemurs. Biol. Conserv. 143, 963-973.

Gaston K.J. \& Spicer J.I. (2004) Biodiversity: An introduction. Blackwell Publishing, Oxford. IPBES (2019) IPBES Global Assessment Summary for Policymakers. Intergovernmental Science-policy Platform on Biodiversity and Ecosystem Services (IPBES), United Nations. 
JANIS (1997) Nationally agreed criteria for the establishment of a comprehensive, adequate and representative reserve system for forests in Australia. Joint ANZECC/MCFFA National Forest Policy Statement Implementation Sub-committee (JANIS), Government of Australia, Canberra.

Joppa L.N., Loarie S.R. \& Pimm S.L. (2008) On the protection of “protected areas". Proc. Natl. Acad. Sci. USA 105, 66736678.

Kearney S.G., Cawardine J., Reside A.E., et al. (2018.) The threats to Australia's imperilled species and implications for a national conservation response. Pac. Conserv. Biol., https://doi.org/10.1071/PC18024.

LCC (1994) Melbourne Area District 2 Review: Final Recommendations. Land Conservation Council, Melbourne. Available from http://www.veac.vic.gov.au/documents/360-FullDoc.pdf.

Lindenmayer D.B., Blair D., McBurney L. \& Banks S.C. (2015a) Ignoring the science in failing to conserve a faunal icon - major political, policy and management problems in preventing the extinction of Leadbeater's possum. Pac. Conserv. Biol. 21, 257-265.

Lindenmayer D.B. \& Burgman M.A. (2005) Practical Conservation Biology. CSIRO Publishing, Melbourne.

Lindenmayer D.B. \& Franklin J.F. (2002) Conserving Forest Biodiversity: A Comprehensive Multiscaled Approach. Island Press, Washington DC.

Lindenmayer D.B., Pierson J., Barton P., et al. (2015b) A new framework for selecting environmental surrogates. Sci. Total Environ. 538, 1029-1038.

Lindenmayer D.B. \& Sato C. (2018) Hidden collapse is driven by fire and logging in a socioecological forest ecosystem. Proc. Natl. Acad. Sci. USA 115, 5181-5186.

Margules C.R. \& Pressey R.L. (2000) Systematic conservation planning. Nature 405, 243253. 
596 Maxwell S., Fuller R.A., Brooks T. \& Watson J. (2016) Biodiversity: The ravages of guns, nets and bulldozers. Nature 536, 143-145.

Moilanen A., Franco A.M., Early R.I., Fox R., Wintle B. \& Thomas C.D. (2005) Prioritizing multiple-use landscapes for conservation: methods for large multi-species planning problems. Proc. R. Soc. B 272, 1885-1891.

Moilanen A., Pouzols F.M., Meller L., et al. (2014) Zonation User Manual, Version 4. C-BIG Conservation Biology Infomatics Group. Department of Biosciences, University of Helsinki, Finland.

Moilanen A. \& Wintle B. (2006) Uncertainty analysis favours selection of spatially aggregated reserve networks. Biol. Conserv. 129, 427-434.

NRMCC (2005) Directions for the National Reserve System - a Partnership Approach. Natural Resource Management Ministerial Council. Department of the Environment and Heritage, Canberra.

Parry B.B. (1997) Abiotic Edge Effects in Wet Sclerophyll Forest in the Central Highlands of Victoria. Masters Thesis. School of Botany. University of Melbourne, Australia.

Pressey R.L., Humphries C.J., Margules C.R., Vane-Wright R.I. \& Williams P.H. (1993) Beyond opportunism: key principles for systematic reserve selection. Trends Ecol. Evol. 8, 124-128.

614 Rodrigues A.S. \& Brooks T.M. (2007) Shortcuts for biodiversity conservation planning: The effectiveness of surrogates. Ann. Rev. Ecol. Evol. S. 38, 713-737.

616 Scott J.M. \& Tear T.H. (2007) What are we conserving? Establishing multiscale conservation goals and objectives in the face of global threats. In: Managing and Designing Landscapes for Conservation. (eds D.B. Lindenmayer and R.J. Hobbs), pp. 494-510. Blackwell Publishing, Oxford. 
620 Taylor C., Cadenhead N., Lindenmayer D.B. \& Wintle B.A. (2017) Improving the design of a conservation reserve for a critically endangered species. PLOS One 12, e 0169629.

Taylor M.F., Fitzsimons J.A. \& Sattler P.S. (2014) Building Nature's Safety Net 2014: A decade of protected area achievements in Australia. WWF-Australia, Sydney.

Todd C.R., Lindenmayer D.B., Stamation K., Acevedo-Catteneo S., Smih S. \& Lumsden L.F. (2016) Assessing reserve effectiveness: Application to a threatened species in a dynamic fire prone forest landscape. Ecol. Model. 338, 90-100.

VEAC (2017) Conservation values of state forests: Assessment report. Victorian Environmental Assessment Council, Melbourne.

Venter O., Magrach A., Outram N., et al. (2018) Bias in protected-area location and its effects on long-term aspirations of biodiversity conventions. Conserv. Biol. 32, 127134.

VicForests (2019a) Approved Timber Release Plan 2019. VicForests, Melbourne. Available from http://www.vicforests.com.au/planning-1/timber-release-plan-1/approvedtimber-release-plan-april-2019. Accessed 5 May 2019.

VicForests (2019b) Timber Release Plan 2019: Spatial Data. VicForests, Melbourne. Available at http://www.vicforests.com.au/planning-1/spatial-data. Accessed 5 May 2019.

VicForests (2019c) VicForests celebrates Victorian forests on World Forest Day. Media release. VicForests, Melbourne. Available from http://www.vicforests.com.au/latestnews/latestnews. Accessed 25 May 2019. 642

Visconti P., Butchart S., Brooks T.M., et al. (2019) Protected area targets post-2020. Science 364, 239-241. 
645 Wilson E.O. (2016) Half Earth: Our Planet's Fight for Life. W.W. Norton, New York.

646

647 


\section{SUPPORTING INFORMATION}

648 Appendix S1. Range of distance from a random point inside protected area to its boundary

649 across all EVC Groups.

650 Appendix S2. Linear weight Zonation for forested areas with conservation reserves and

651 historic logging.

652 Appendix S3. Log weight Zonation for forested areas with conservation reserves and historic 653 logging.

654 Appendix S4. Equal weight Zonation for and use categories and areas allocated for logging.

655 Appendix S5. Linear weight Zonation for land use categories and areas allocated for logging.

656 Appendix S6. Log weight Zonation for land use categories and areas allocated for logging.

657 Appendix S7. Equal weight Zonation for EVC Groups.

658 Appendix S8. Linear weight Zonation for EVC Groups.

659 Appendix S9. Log weight Zonation for EVC Groups.

660 Appendix S10. Linear weight Zonation prioritisation scores for EVC Group areas subject to

661 clearfell logging.

662 Appendix S11. Log weight Zonation prioritisation scores for EVC Group areas subject to 663 clearfell logging.

664 Appendix S12. List of forest dependent threatened species modelled in this study.

665 Appendix S13. The area of forest and woodland EVC Groups derived from EVC Group 666 dataset.

667 Appendix S14. Tukey's HSD test for equal weight Zonation.

668 Appendix S15. Tukey's HSD test for linear Zonation.

669 Appendix S16. Tukey's HSD test for log weight Zonation.

670 Appendix S17. Tukey's HSD test for all weights Zonation. 
671 Appendix S18. Area Analysis of the top scoring 10 percent for the equal, linear and log

672 Weight Zonation 
Table 1. Three weighting schemes for the species' threatened status used in this study

\begin{tabular}{lllll}
\hline IUCN Red List & Example Species & Equal Weight & Linear & Log Weight \\
Category & & & Weight & \\
\hline Critically Endangered & Leadbeater's Possum & 1 & 4 & 0.5 \\
Endangered & Long-footed Potoroo & 1 & 3 & 0.05 \\
Vulnerable & Greater Glider & 1 & 2 & 0.005 \\
Near Threatened & Yellow-bellied Glider & 1 & 1 & 0.0005 \\
\hline
\end{tabular}


Table 2. Areas of different land uses in Victoria with data sourced from ACLUMP

(ABARES 2011) and forest management zones (DELWP 2019b)

\begin{tabular}{|c|c|c|c|c|}
\hline Land Tenure & Zone & Protection Status & Area (ha) & $\%$ of Total \\
\hline Conservation and & Conservation Reserve & Dedicated Reserve & $4,404,763$ & $19 \%$ \\
\hline \multirow[t]{3}{*}{ Parks } & Other Parks & Other Parks & 25,553 & $0 \%$ \\
\hline & Subtotal for Conservation & & $4,430,317$ & $19 \%$ \\
\hline & and Parks & & & \\
\hline \multirow[t]{7}{*}{ State Forest } & Special Protection Zone & Informal Protection & 780,005 & $3 \%$ \\
\hline & Code of Forest Practice & Informal Protection & 348,371 & $2 \%$ \\
\hline & Exclusion & & & \\
\hline & General Management Zone & Logging permitted & $1,604,132$ & $7 \%$ \\
\hline & Special Management Zone & Logging permitted & 145,692 & $1 \%$ \\
\hline & Other State Forest & Not Protected & 397,904 & $2 \%$ \\
\hline & Subtotal for State Forests & & $3,276,105$ & $14 \%$ \\
\hline Historic Reserve & Other Parks & Logging permitted & 38,633 & $0 \%$ \\
\hline Agriculture & Agriculture & Private Land & $13,250,902$ & $58 \%$ \\
\hline Plantation & Plantation & Private Land & 571,570 & $3 \%$ \\
\hline Intensive & Urban and Intensive Use & Private Land and Roads & 992,481 & $4 \%$ \\
\hline Mining and Waste & Industrial & Private Land & 43,915 & $0 \%$ \\
\hline Water & Environment/Services & Private/Public & 120,668 & $1 \%$ \\
\hline Other Land Use & Miscellaneous & Private/Public & 114,822 & $1 \%$ \\
\hline Total & & & $22,839,413$ & $100 \%$ \\
\hline
\end{tabular}


Table 3. Tukey's HSD test for random points inside the protected area network to a boundary for Wet and Damp Forests, Dry Forest, and Mallee EVC Groups $(\mathrm{P}<0.05)$

\begin{tabular}{llllll}
\hline EVC Group & Reserve Type Comparison & diff & lwr & upr & p \\
\hline Dry Forest & Informal Protected Area-Dedicated & -1667.859 & -1769.456 & -1566.262 & 0 \\
& Reserve & & & & \\
Mallee & Other Parks-Dedicated Reserve & -6745.794 & -11743.58 & -1748.004 & 0.008 \\
Wet and Damp & Informal Protected Area -Dedicated & -2129.195 & -2266.436 & -1991.953 & 0 \\
Forest & Reserve & & & & \\
\hline Overall EVC Groups & Informal Protected Area -Dedicated & -3184.3398 & -3346.514 & -3022.165 & 0 \\
& Reserve & & & & \\
& Other Parks-Dedicated Reserve & -3170.047 & -4196.977 & -2143.117 & 0 \\
& Other Parks-Informal Protected Area & 14.29282 & -1019.842 & 1048.428 & 0.999 \\
\hline
\end{tabular}


Table 4. Tukey's HSD test for equal weight Zonation results between land tenures and forest management zones. Bold text denotes statistical significance $\mathrm{P}<0.05$ ).

\begin{tabular}{lllll}
\hline Land Tenure Comparison & diff & lwr & upr & p adj \\
\hline Informal Protected Area-Dedicated Reserve & $\mathbf{0 . 1 9 1}$ & $\mathbf{0 . 1 7 3}$ & $\mathbf{0 . 2 0 8}$ & $\mathbf{0 . 0 0 0}$ \\
Logging Permitted-Dedicated Reserve & $\mathbf{0 . 2 2 4}$ & $\mathbf{0 . 2 1 0}$ & $\mathbf{0 . 2 3 9}$ & $\mathbf{0 . 0 0 0}$ \\
Other Parks-Dedicated Reserve & -0.109 & -0.232 & 0.015 & 0.122 \\
Other State Forest-Dedicated Reserve & $\mathbf{- 0 . 1 3 3}$ & $\mathbf{- 0 . 1 6 1}$ & $\mathbf{- 0 . 1 0 6}$ & $\mathbf{0 . 0 0 0}$ \\
Private Land-Dedicated Reserve & 0.002 & -0.014 & 0.019 & 0.998 \\
Logging Permitted-Informal Protected Area & $\mathbf{0 . 0 3 4}$ & $\mathbf{0 . 0 1 4}$ & $\mathbf{0 . 0 5 3}$ & $\mathbf{0 . 0 0 0}$ \\
Other Parks-Informal Protected Area & $\mathbf{- 0 . 2 9 9}$ & $\mathbf{- 0 . 4 2 4}$ & $\mathbf{- 0 . 1 7 5}$ & $\mathbf{0 . 0 0 0}$ \\
Other State Forest-Informal Protected Area & $\mathbf{- 0 . 3 2 4}$ & $\mathbf{- 0 . 3 5 5}$ & $\mathbf{- 0 . 2 9 3}$ & $\mathbf{0 . 0 0 0}$ \\
Private Land-Informal Protected Area & $\mathbf{- 0 . 1 8 8}$ & $\mathbf{- 0 . 2 1 0}$ & $\mathbf{- 0 . 1 6 7}$ & $\mathbf{0 . 0 0 0}$ \\
Other Parks-Logging Permitted & $\mathbf{- 0 . 3 3 3}$ & $\mathbf{- 0 . 4 5 7}$ & $\mathbf{- 0 . 2 0 9}$ & $\mathbf{0 . 0 0 0}$ \\
Other State Forest-Logging Permitted & $\mathbf{- 0 . 3 5 8}$ & $\mathbf{- 0 . 3 8 7}$ & $\mathbf{- 0 . 3 2 9}$ & $\mathbf{0 . 0 0 0}$ \\
Private Land-Logging Permitted & $\mathbf{- 0 . 2 2 2}$ & $\mathbf{- 0 . 2 4 1}$ & $\mathbf{- 0 . 2 0 3}$ & $\mathbf{0 . 0 0 0}$ \\
Other State Forest-Other Parks & -0.025 & -0.151 & 0.101 & 0.994 \\
Private Land-Other Parks & 0.111 & -0.013 & 0.235 & 0.110 \\
Private Land-Other State Forest & $\mathbf{0 . 1 3 6}$ & $\mathbf{0 . 1 0 5}$ & $\mathbf{0 . 1 6 6}$ & $\mathbf{0 . 0 0 0}$ \\
\hline
\end{tabular}


Table 5. Tukey's HSD test for equal weight Zonation results between areas previously clearfell logged post 1970, areas scheduled for clearfell logging under the 2019 Timber Release Plan and remaining EVC Group area not logged. Bold text denotes statistical significance $\mathrm{P}<0.05$.

\begin{tabular}{llcccc}
\hline EVC Group & Sequence & Diff & Lower & Upper & P adj \\
\hline Wet and Damp Forest & Remaining Area of EVC & $\mathbf{0 . 0 4 4}$ & $\mathbf{0 . 0 2 9}$ & $\mathbf{0 . 0 5 8}$ & $\mathbf{0 . 0 0 0}$ \\
& Group/Previously Logged & & & & \\
Wet and Damp Forest & Remaining Area of EVC Group & $\mathbf{0 . 0 5 7}$ & $\mathbf{0 . 0 3 0}$ & $\mathbf{0 . 0 8 3}$ & $\mathbf{0 . 0 0 0}$ \\
& /TRP 2019 & & & & \\
Wet and Damp Forest & Previously Logged/TRP 2019 & 0.013 & -0.016 & 0.042 & 0.546 \\
\hline Dry Forest & Remaining Area of EVC & $\mathbf{0 . 0 7 9}$ & $\mathbf{0 . 0 4 5}$ & $\mathbf{0 . 1 1 3}$ & $\mathbf{0 . 0 0 0}$ \\
& Group/Previously Logged & & & & \\
Dry Forest & Remaining Area of EVC Group & $\mathbf{0 . 1 0 8}$ & $\mathbf{0 . 0 3 4}$ & $\mathbf{0 . 1 8 2}$ & $\mathbf{0 . 0 0 2}$ \\
& /TRP 2019 & & & & \\
Dry Forest & Previously Logged/TRP 2019 & 0.029 & -0.052 & 0.109 & 0.685 \\
\hline All Forest EVCs & Remaining Area of EVC & $\mathbf{0 . 2 4 6}$ & $\mathbf{0 . 2 1 8}$ & $\mathbf{0 . 2 7 4}$ & $\mathbf{0 . 0 0 0}$ \\
& Group/Previously Logged & & & & \\
All Forest EVCs & Remaining Area of EVC Group & $\mathbf{0 . 2 5 6}$ & $\mathbf{0 . 1 9 9}$ & $\mathbf{0 . 3 1 2}$ & $\mathbf{0 . 0 0 0}$ \\
& /TRP 2019 & & & & \\
\hline & Previously Logged/TRP 2019 & 0.010 & -0.053 & 0.073 & 0.925 \\
\hline
\end{tabular}




\section{FIGURES}

Fig. 1. Land tenure and forest management zones across Victoria

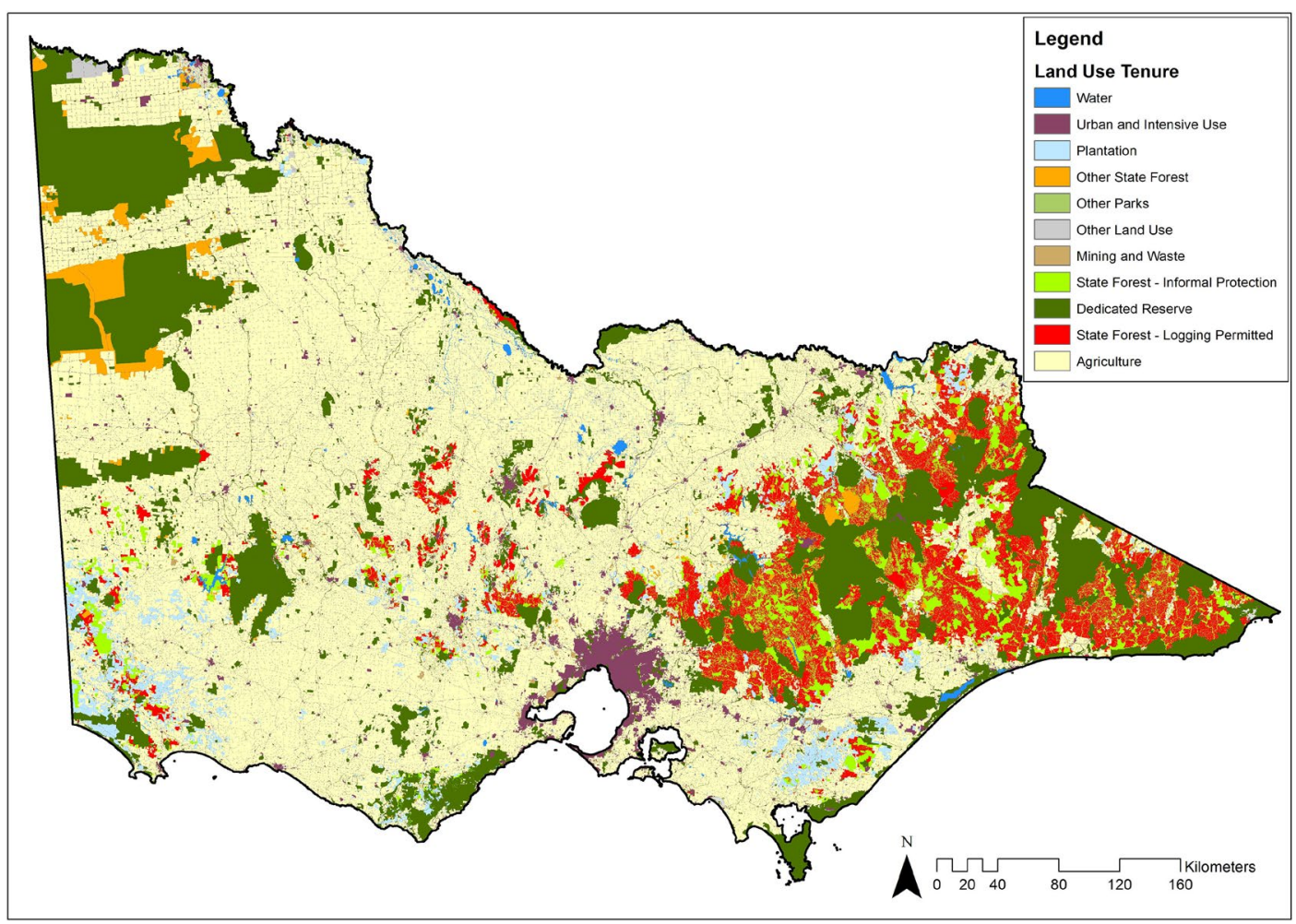

Fig. 2. Ecological Vegetation Class (EVC) Groups, conservation reserves and historic clearcutting

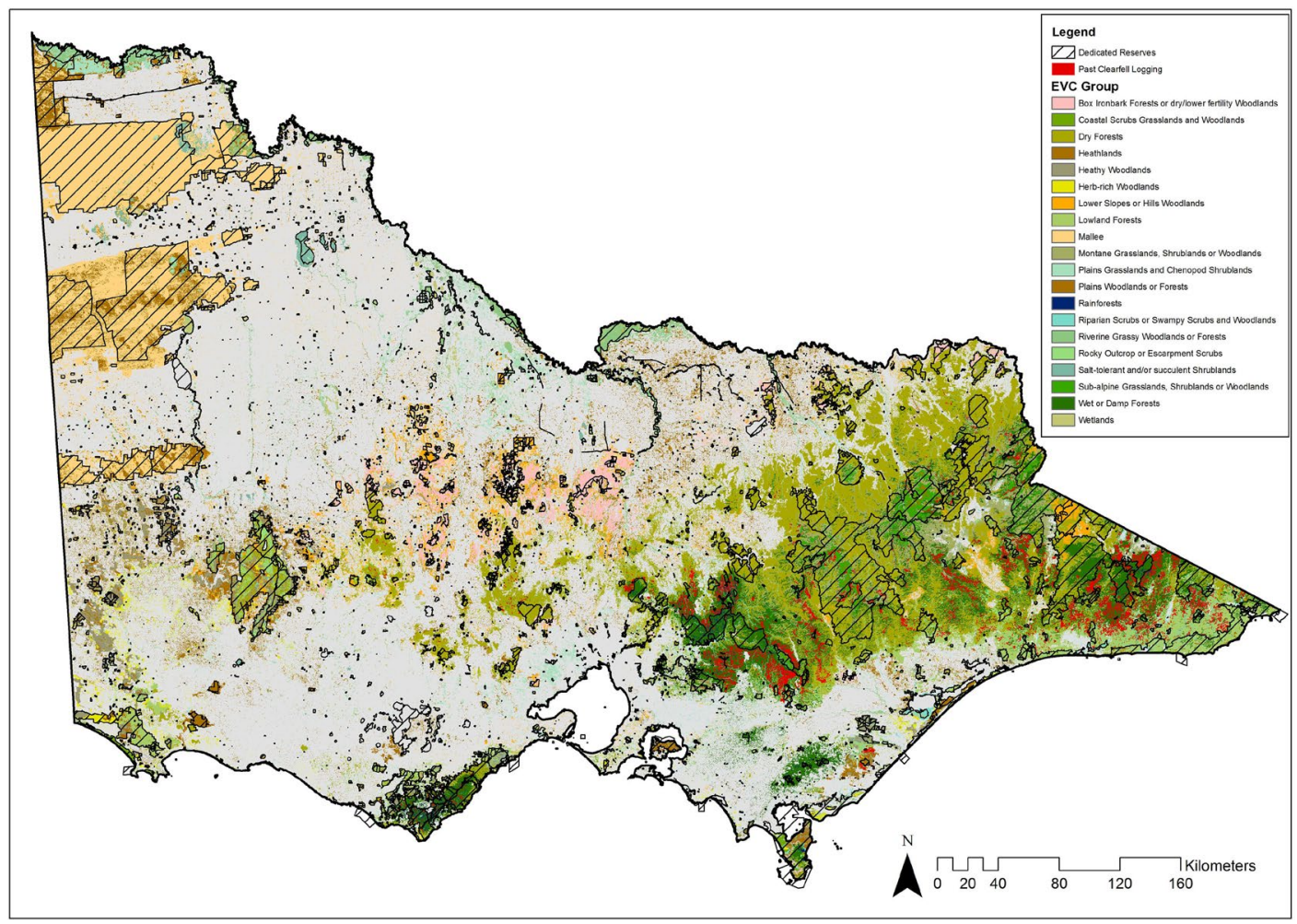


Fig. 3. EVC Group and land tenure classification by area

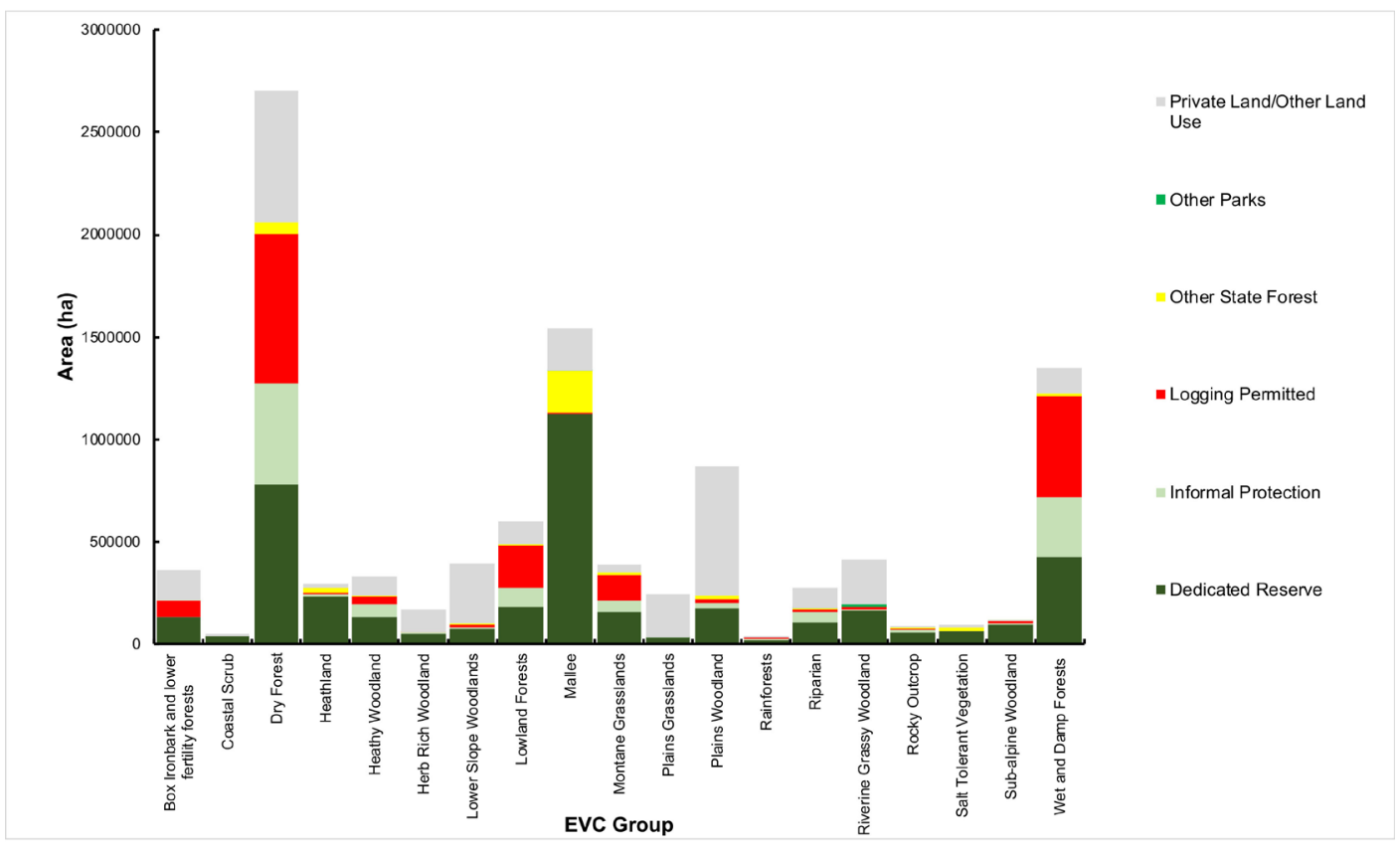

Fig. 4. Range of distance from a random point inside protected area to its boundary for the Dry Forest EVC Group (left), the Mallee EVC Group (centre) and the Wet and Damp EVC

\section{Group (right)}

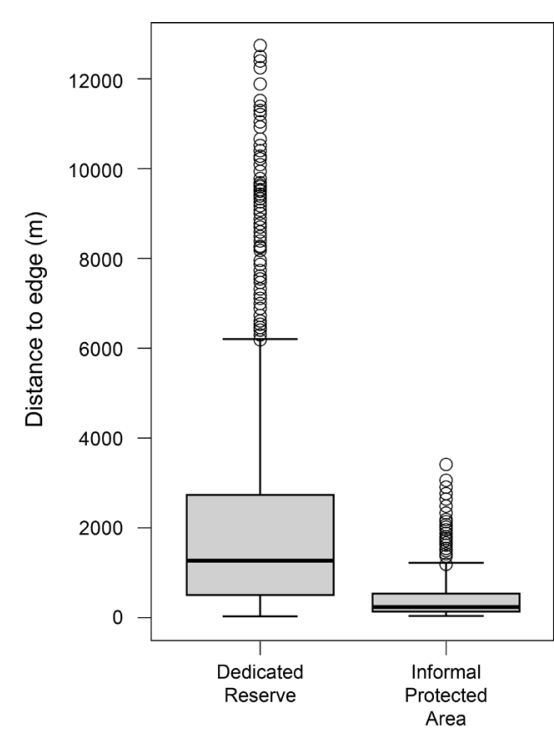

Dry Forest EVC Group

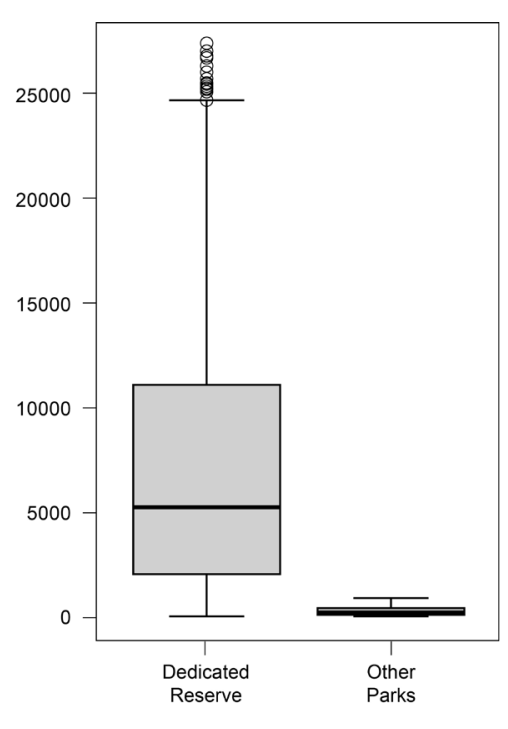

Mallee EVC Group

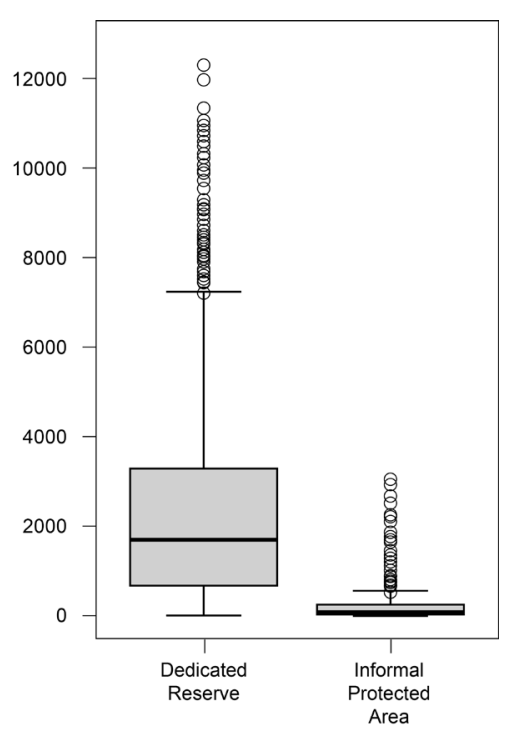

Wet and Damp Forest EVC Group 
Fig. 5. Historic logging across the EVC Groups

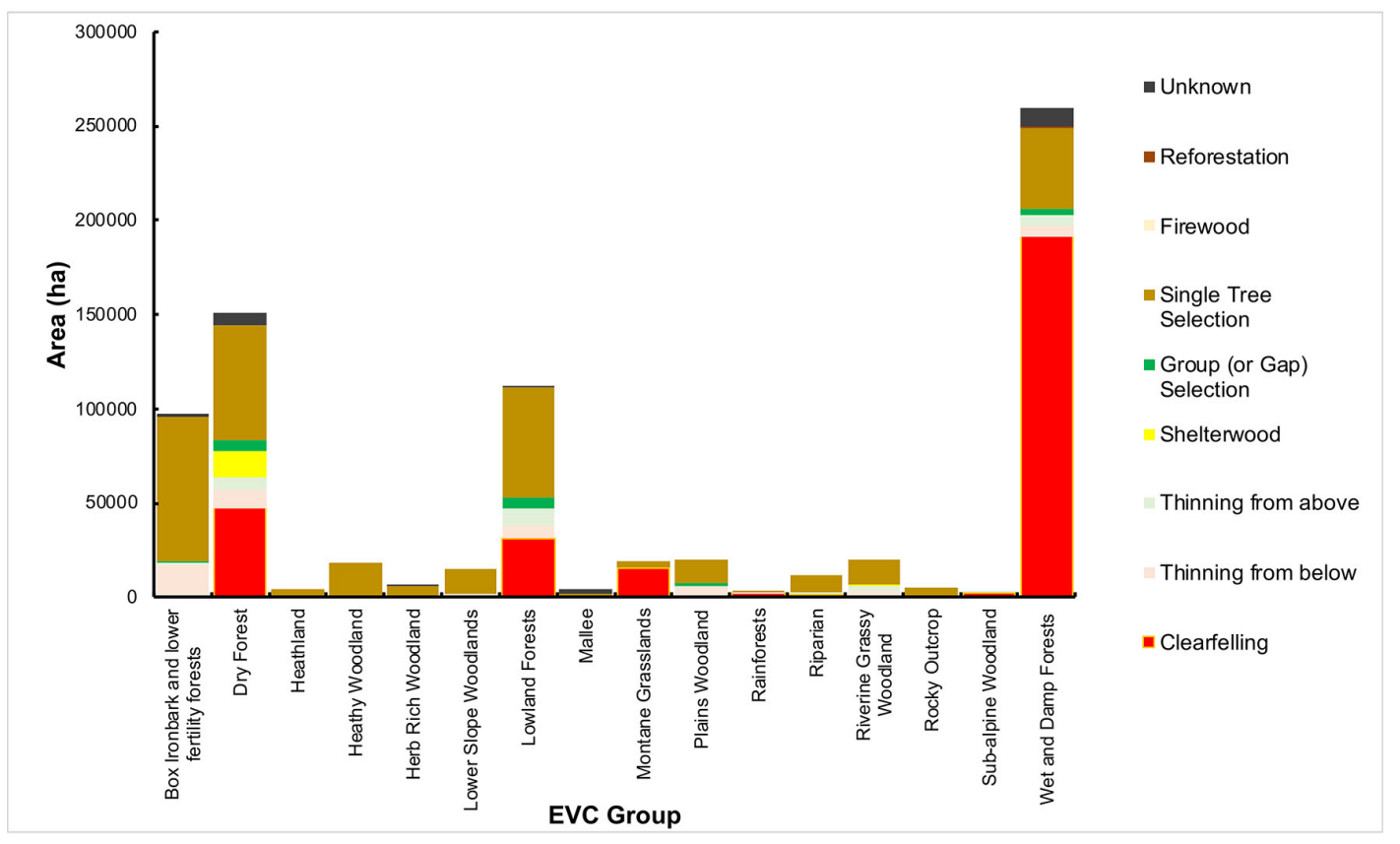

Fig. 6. Equal weight Zonation for forested areas with conservation reserves and historic logging overlaid

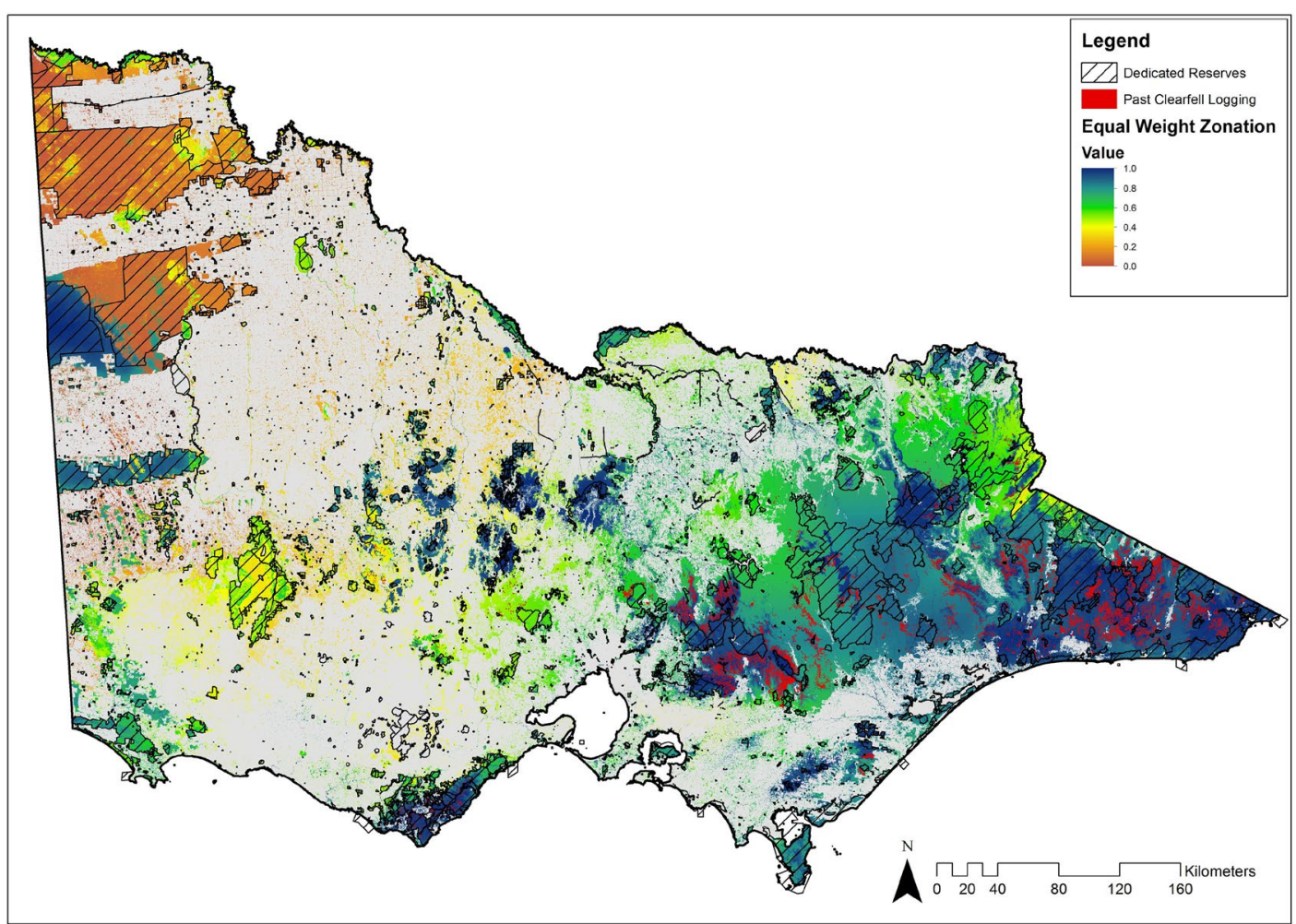


Fig. 7. Equal weight Zonation scores for selected land tenure across Victoria

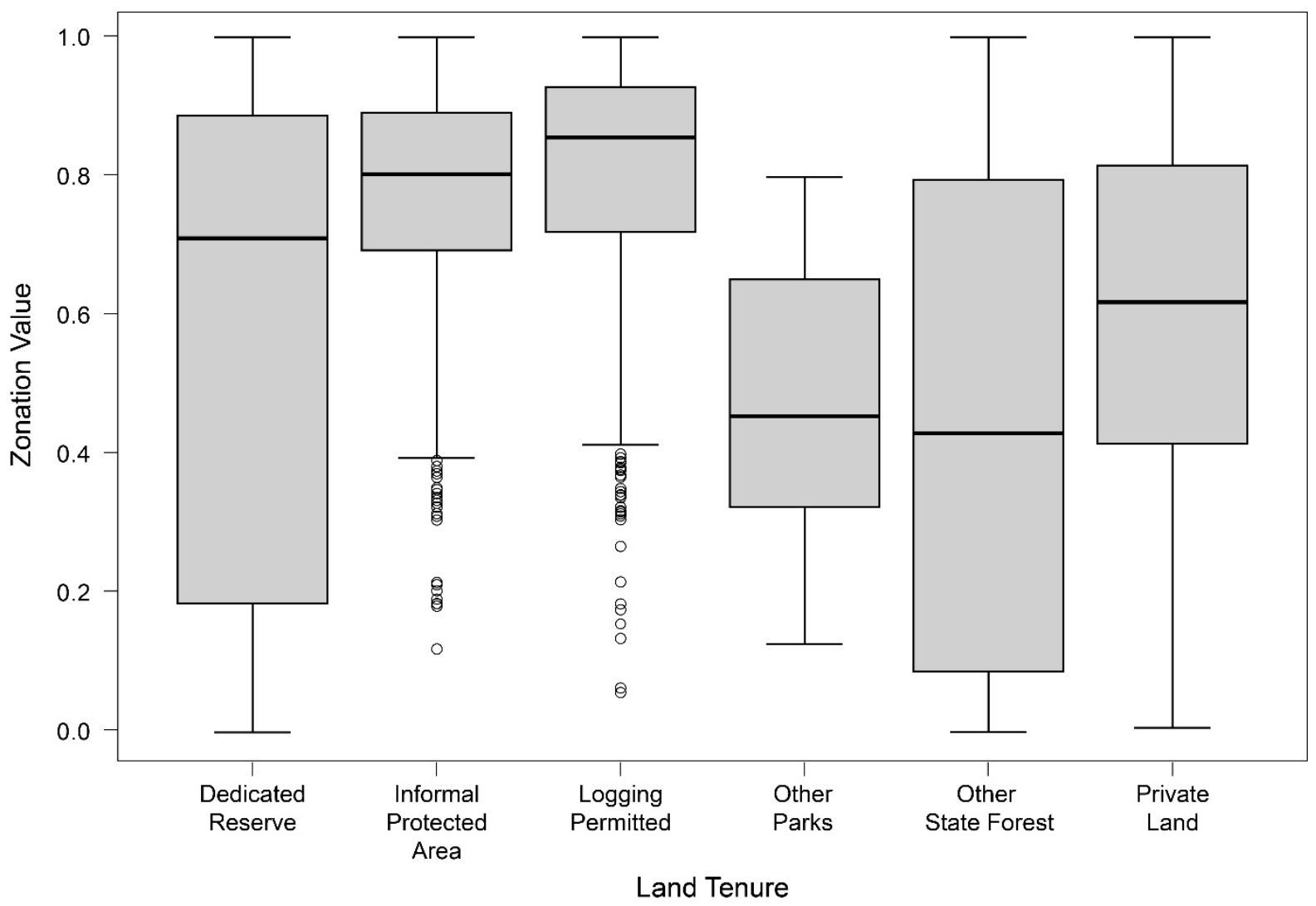

Fig. 8. Equal Weight Zonation prioritisation scores for selected EVC Groups
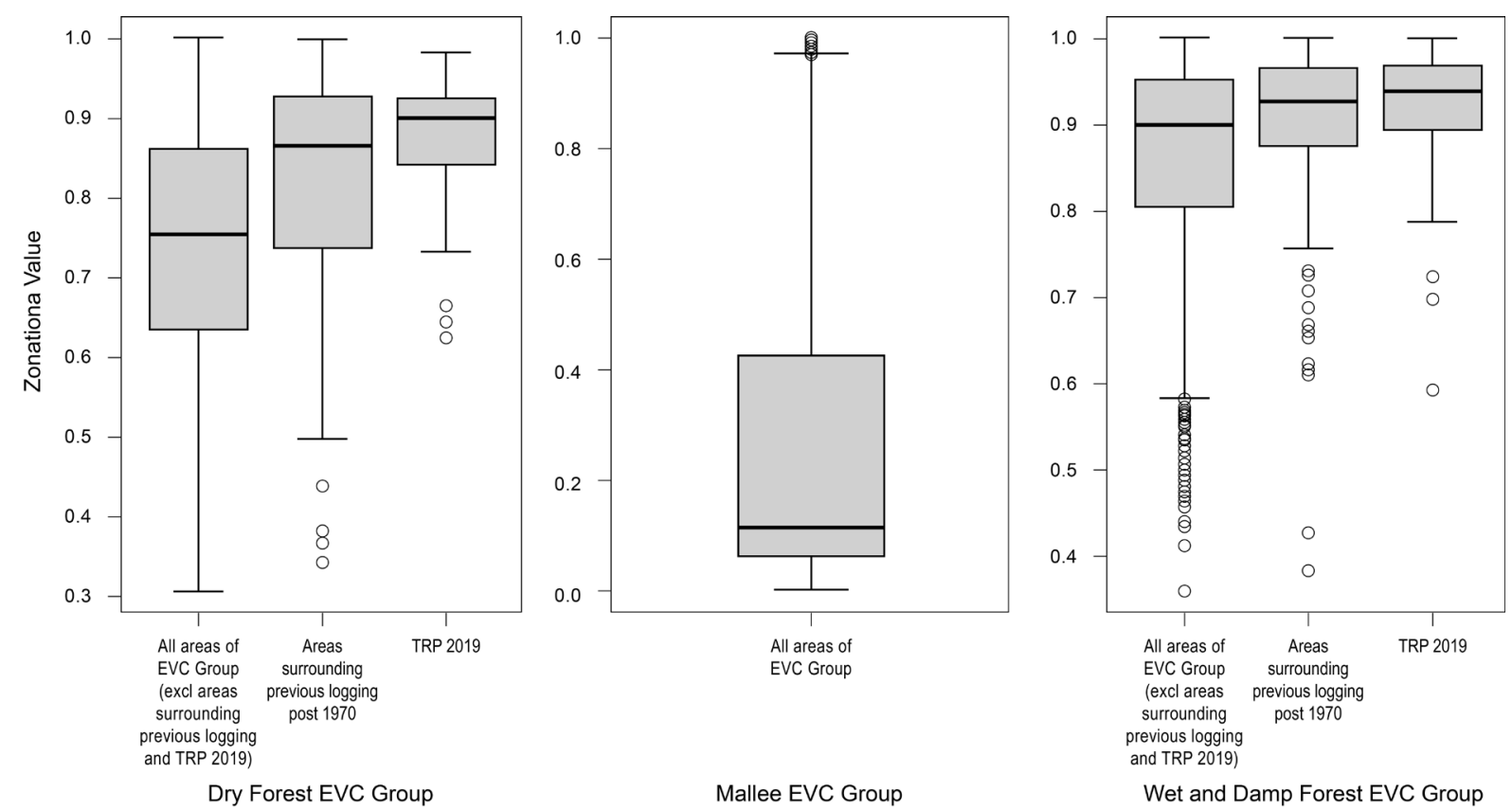
The adequacy of Victoria's protected areas for conserving its forest-dependent fauna SUPPORTING INFORMATION

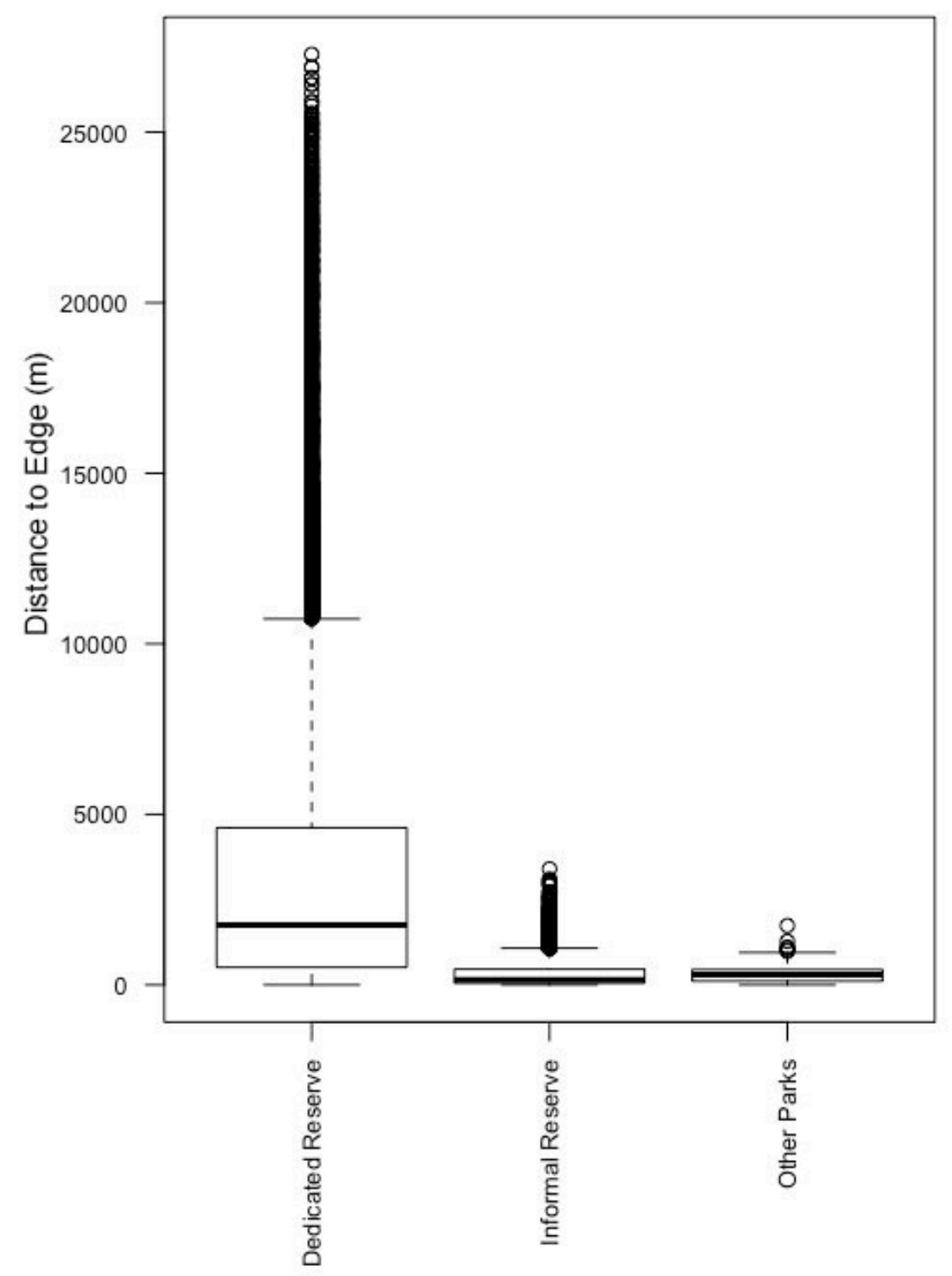

Appendix S1. Range of distance from a random point inside protected area to its boundary across all EVC Groups 


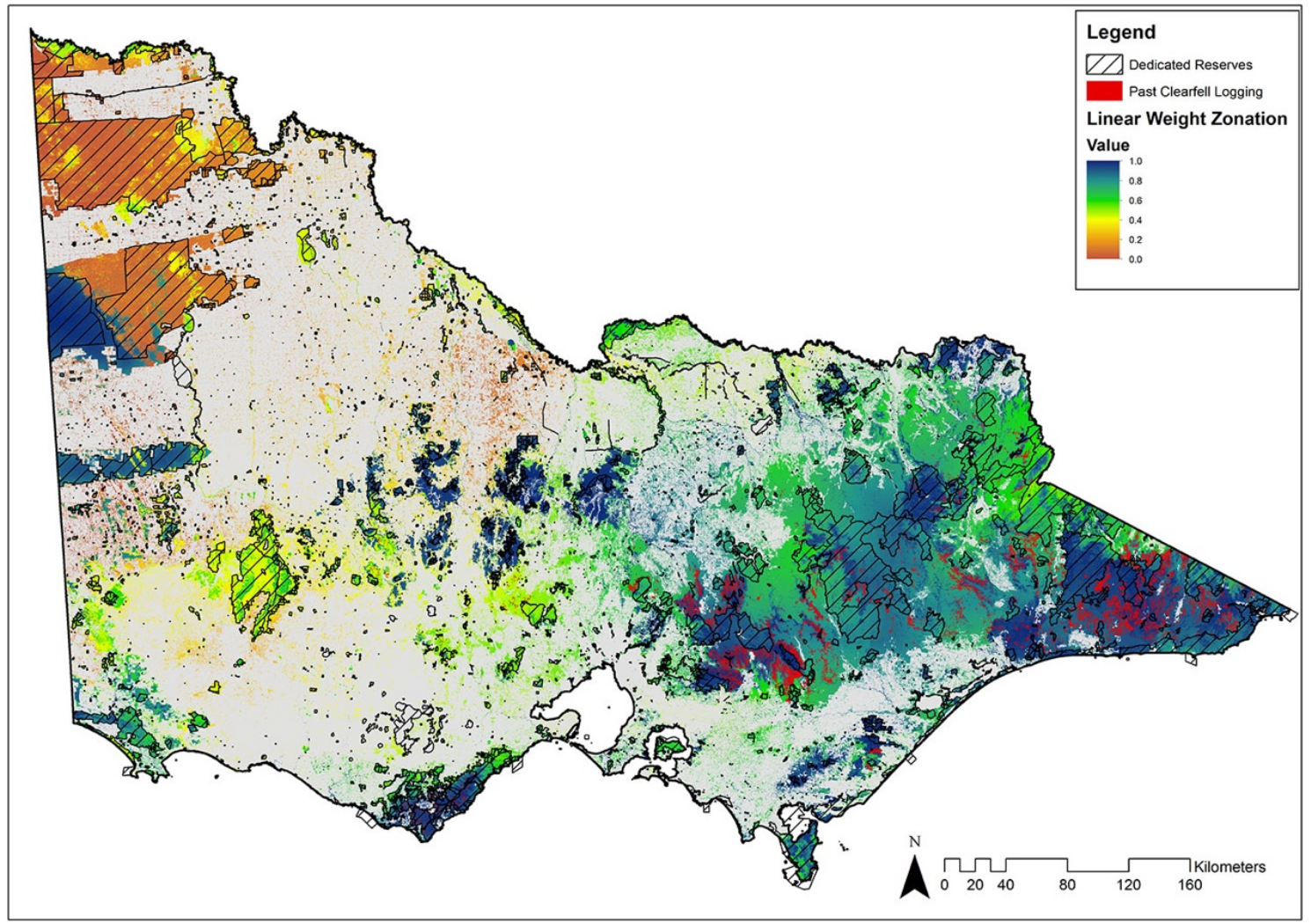

Appendix S2. Linear weight Zonation for forested areas with conservation reserves and historic logging overlaid

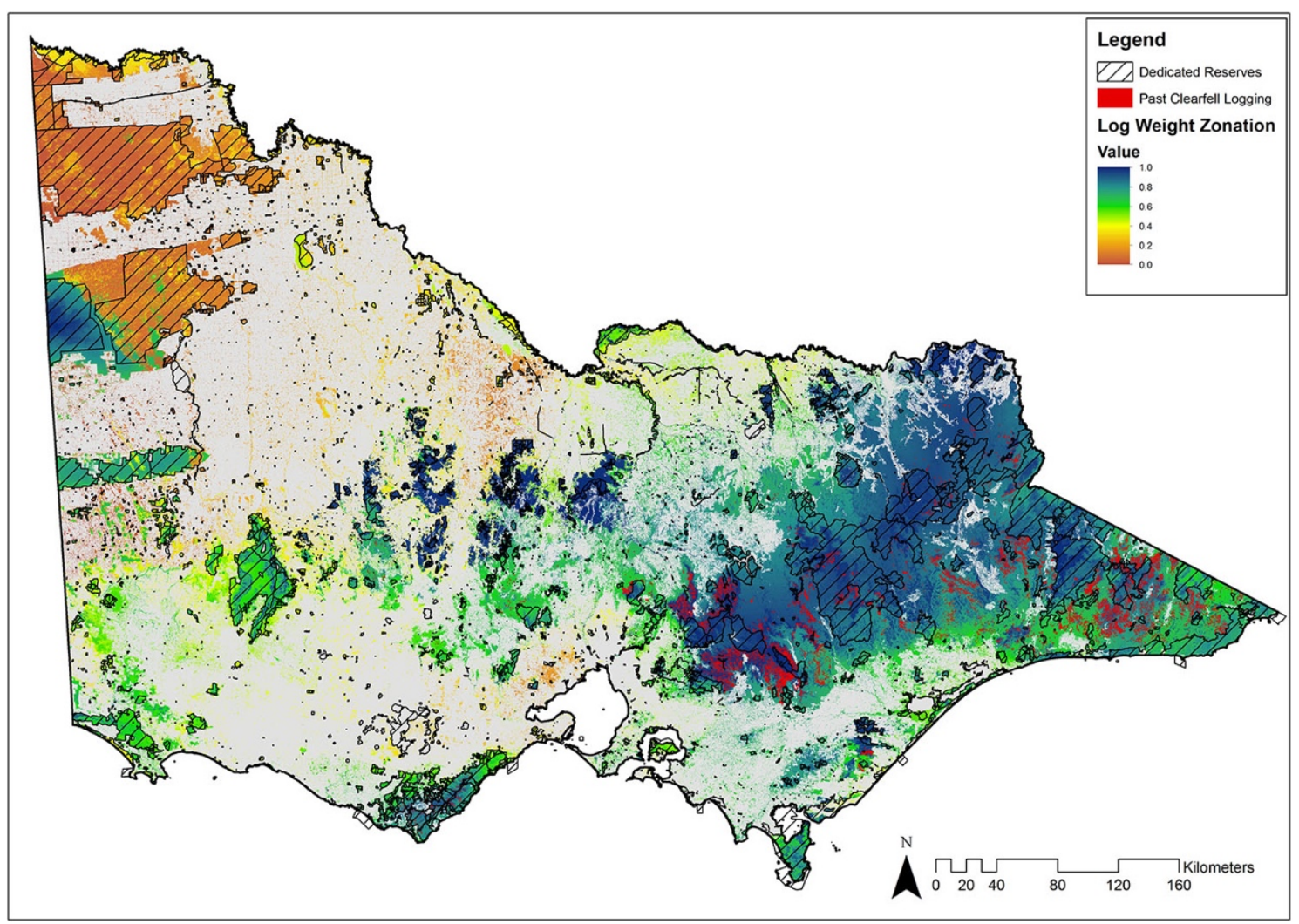

Appendix S3. Log weight Zonation for forested areas with conservation reserves and historic logging overlaid 


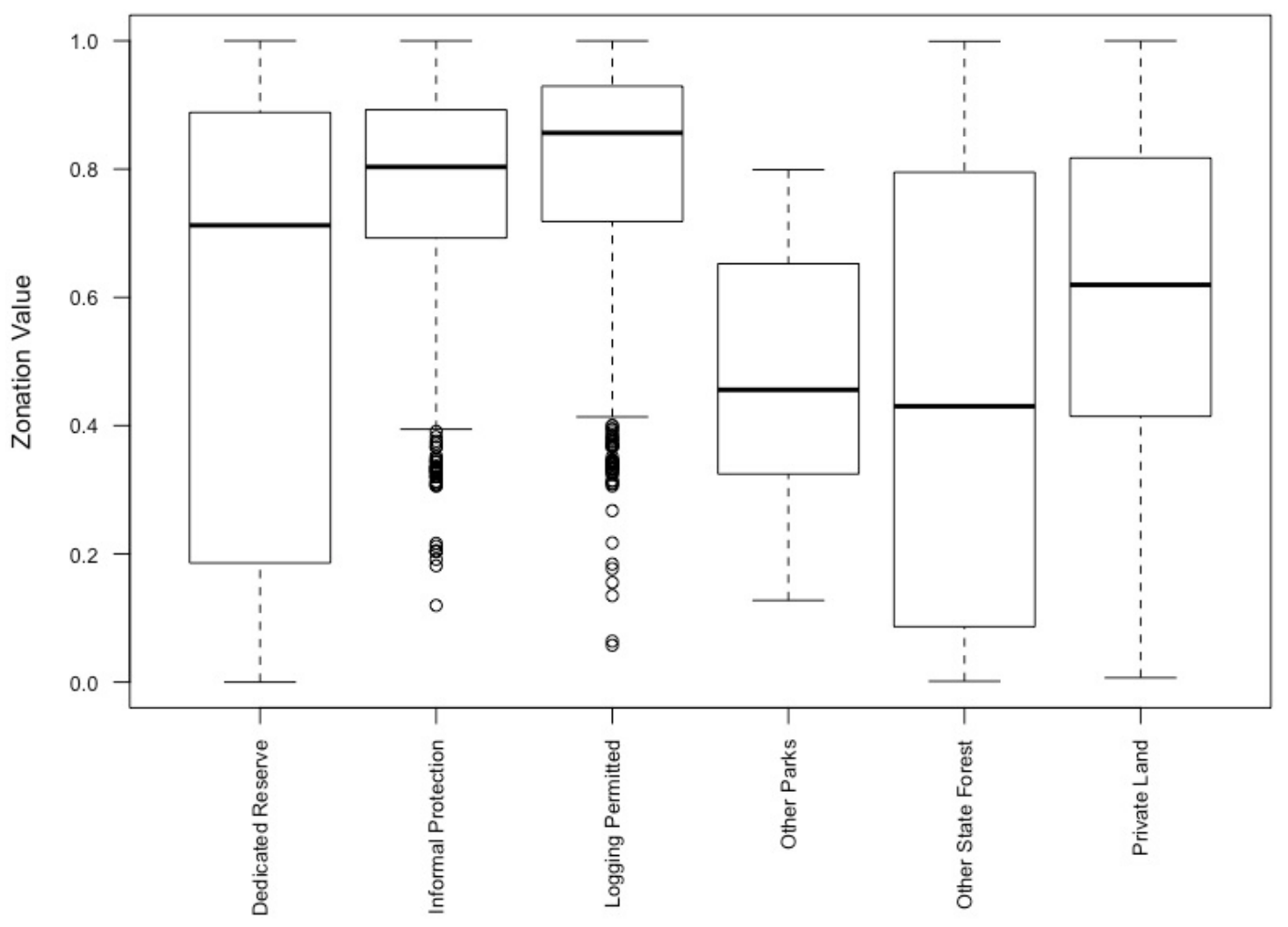

Appendix S4. Equal weight Zonation for ACLUMP derived land use categories and areas allocated for logging

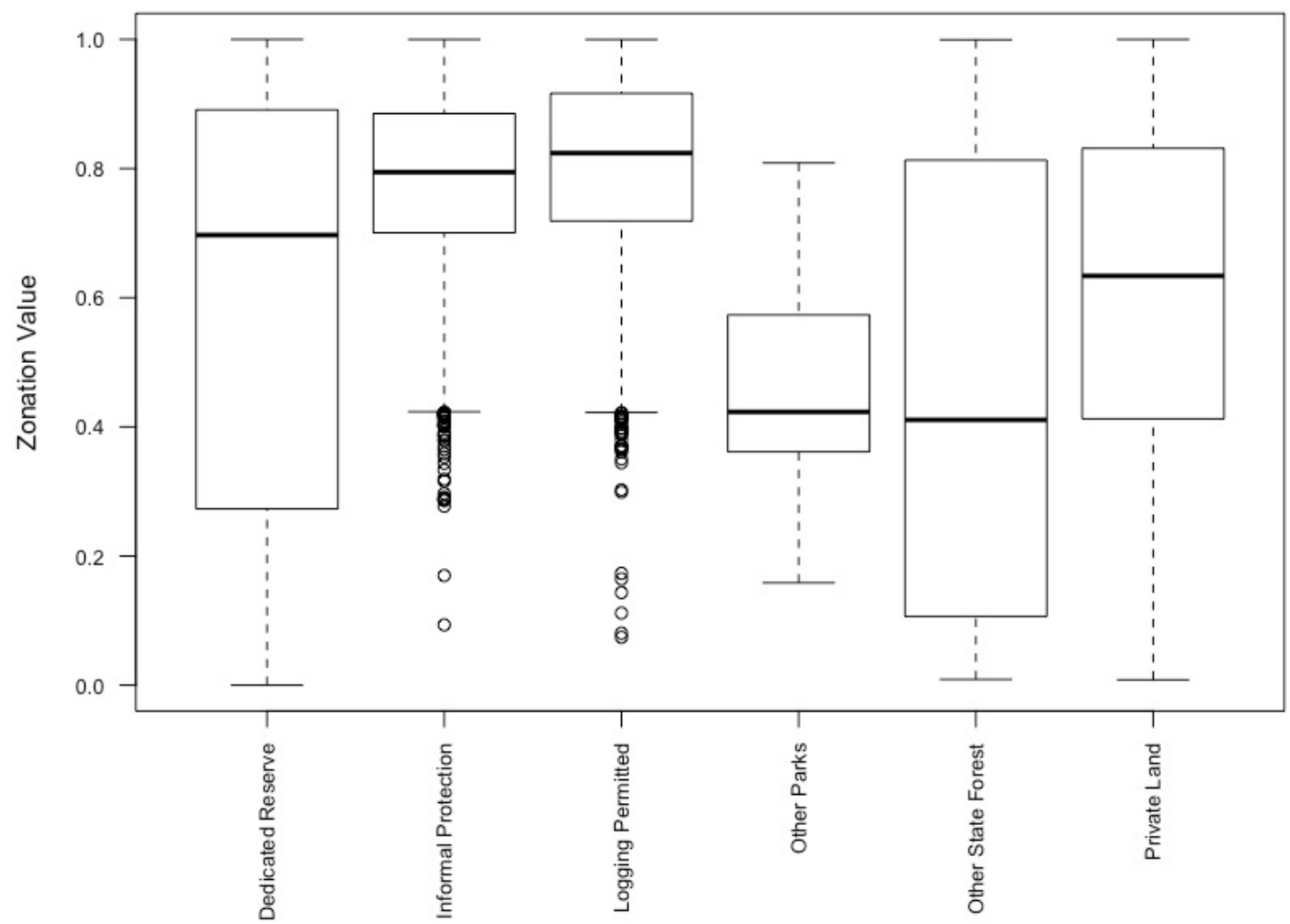

Appendix S5. Linear weight Zonation for ACLUMP derived land use categories and areas allocated for logging 


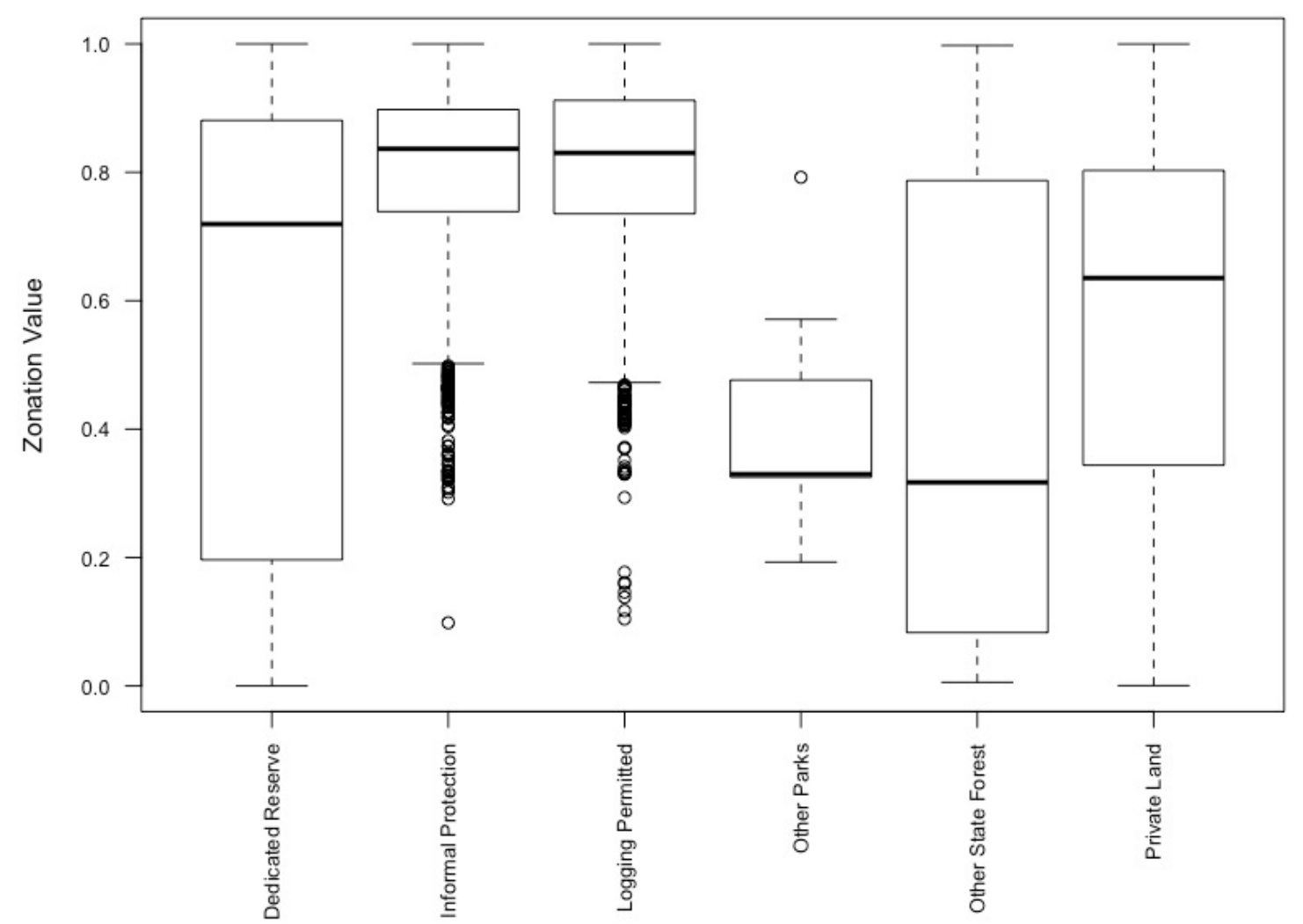

Appendix S6. Log weight Zonation for ACLUMP derived land use categories and areas allocated for logging

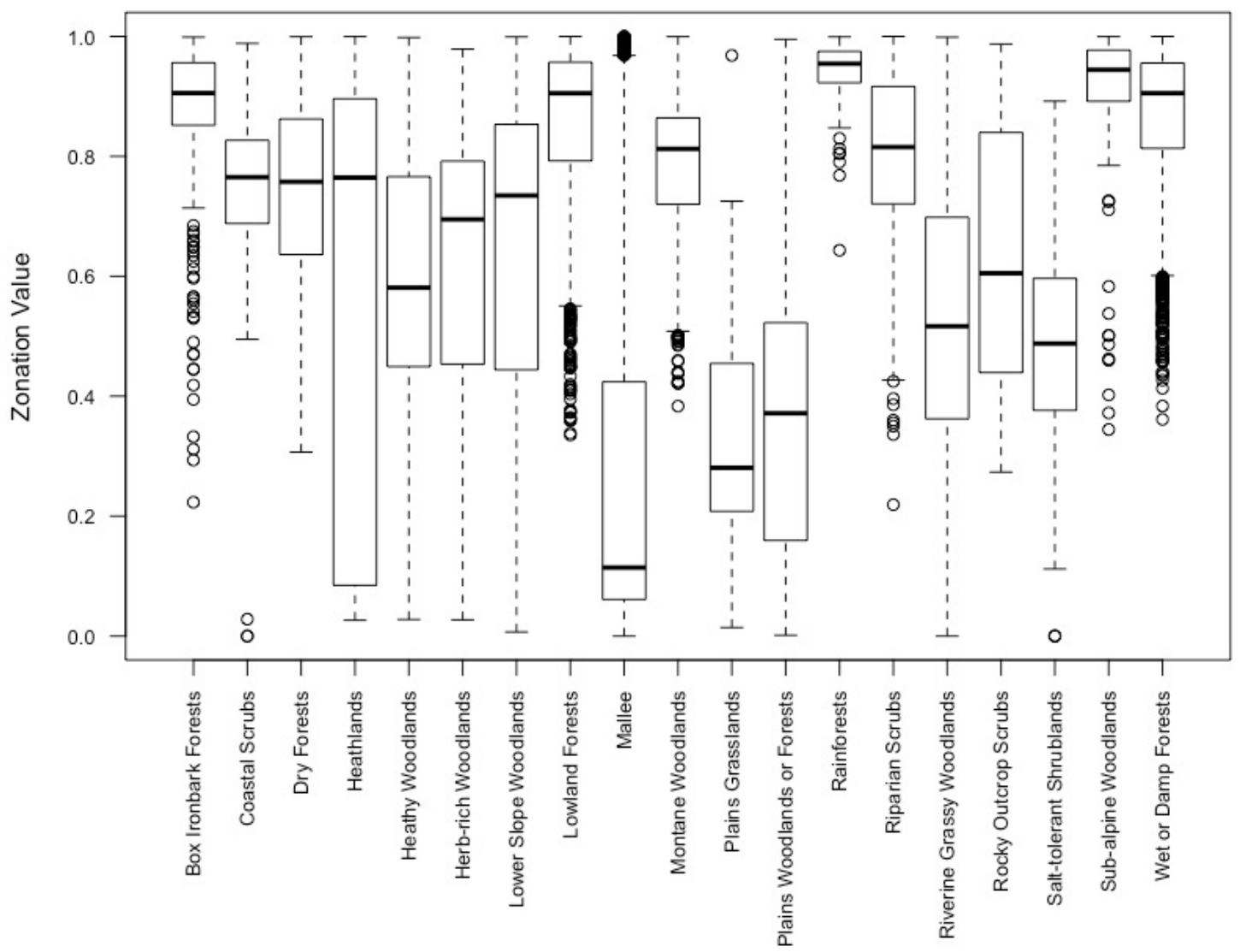

Appendix S7. Equal weight Zonation for EVC Groups 


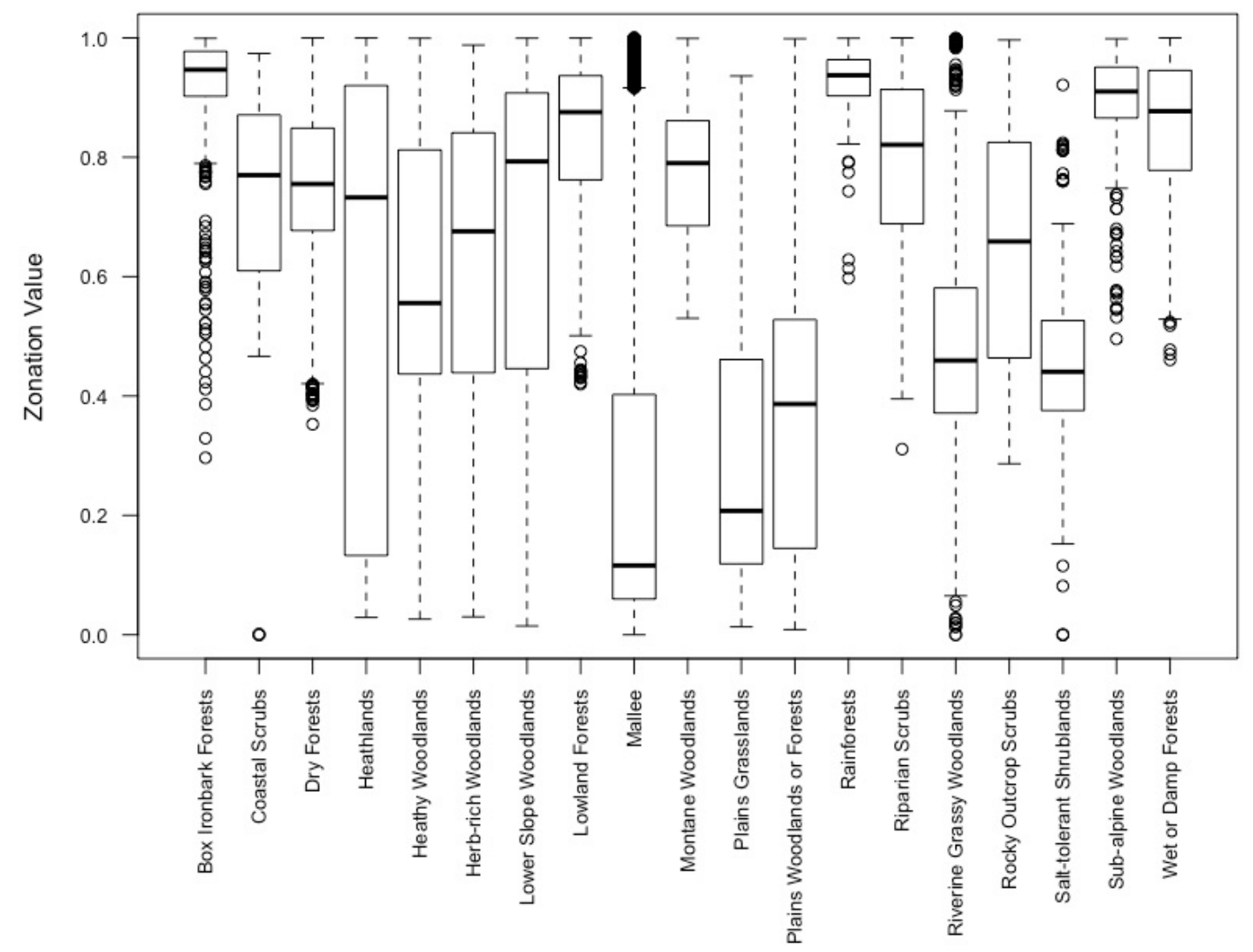

Appendix S8. Linear weight Zonation for EVC Groups

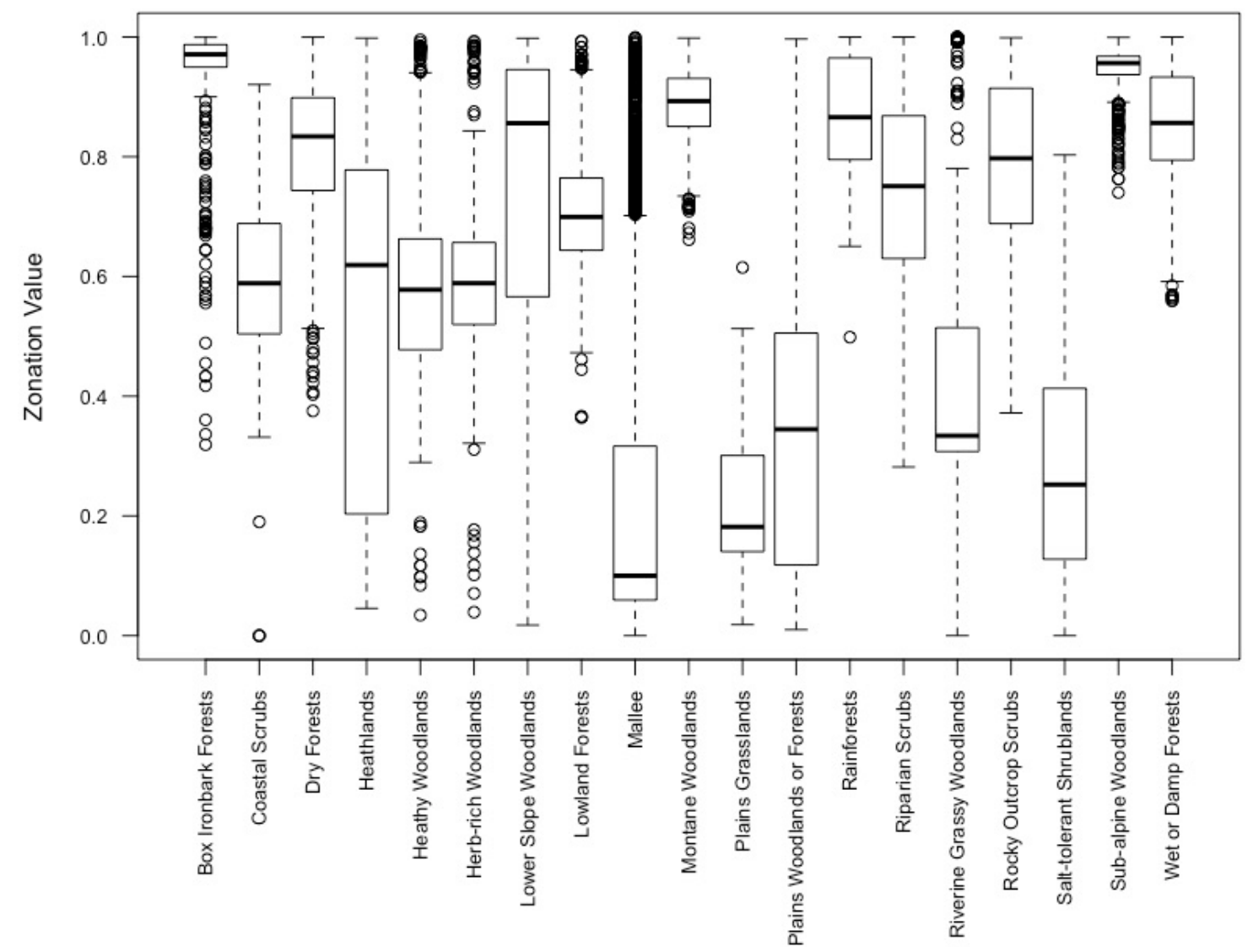

Appendix S9. Log weight Zonation for EVC Groups 


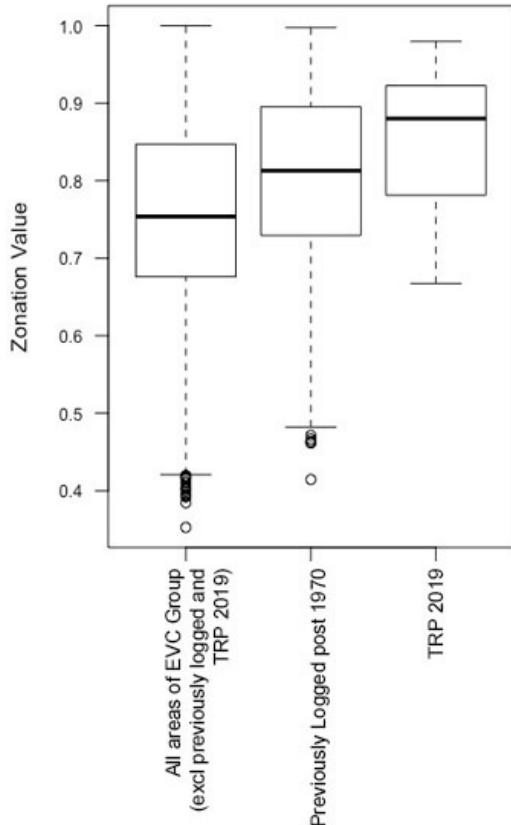

Dry Forest EVC Group

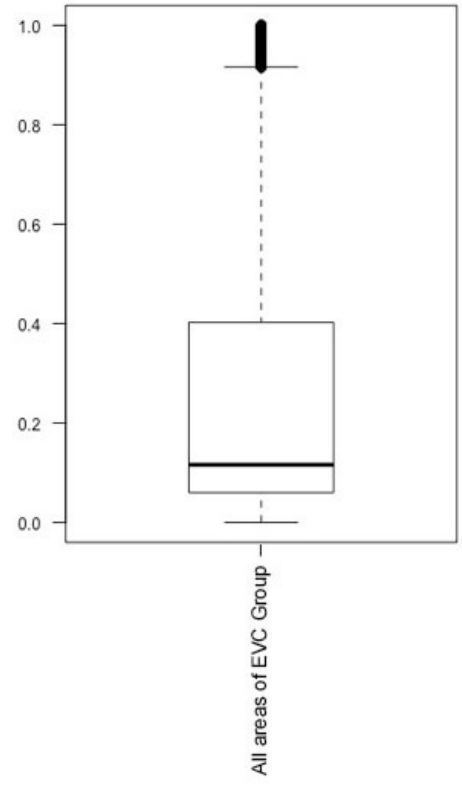

Mallee EVC Group

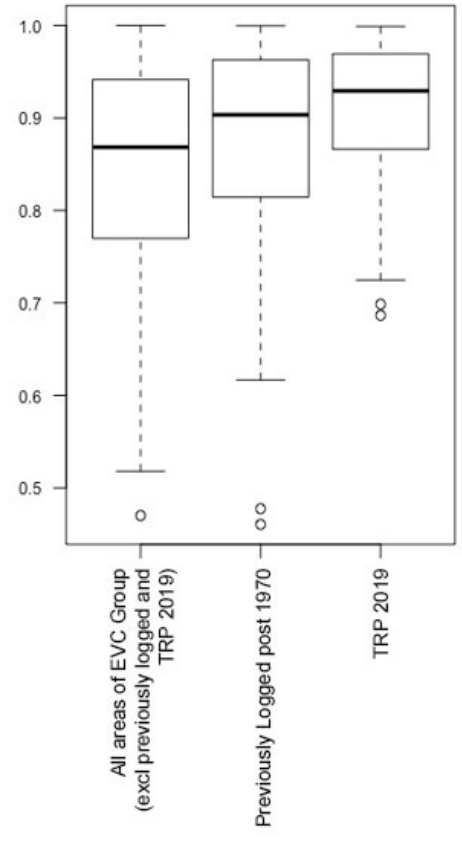

Wet and Damp EVC Group

Appendix S10. Linear weight Zonation prioritisation scores for Dry Forest EVC Group (left), Mallee EVC Group (middle) and Wet or Damp Forest EVC Group (right) subject to clearfell logging

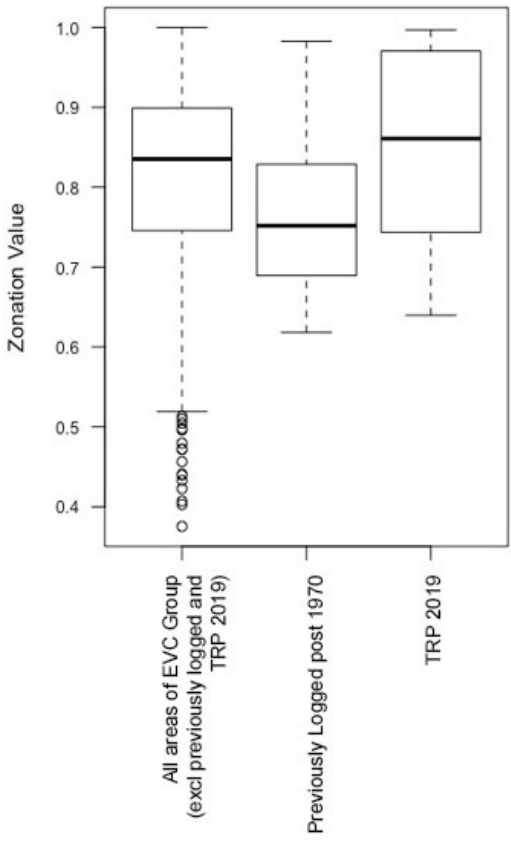

Dry Forest EVC Group

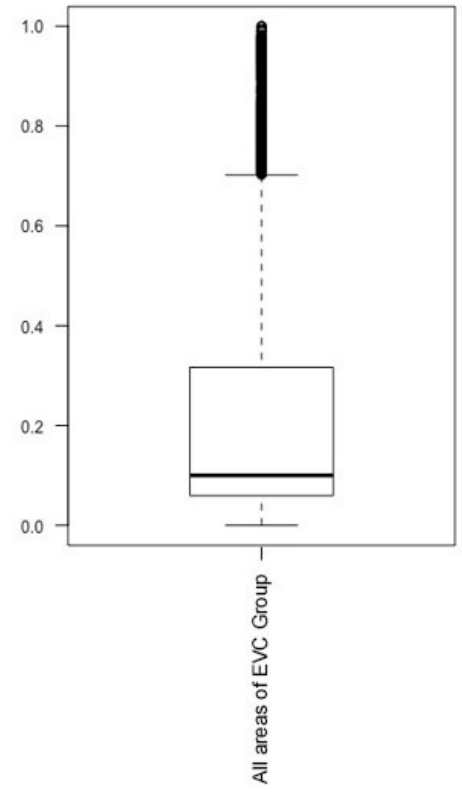

Mallee EVC Group

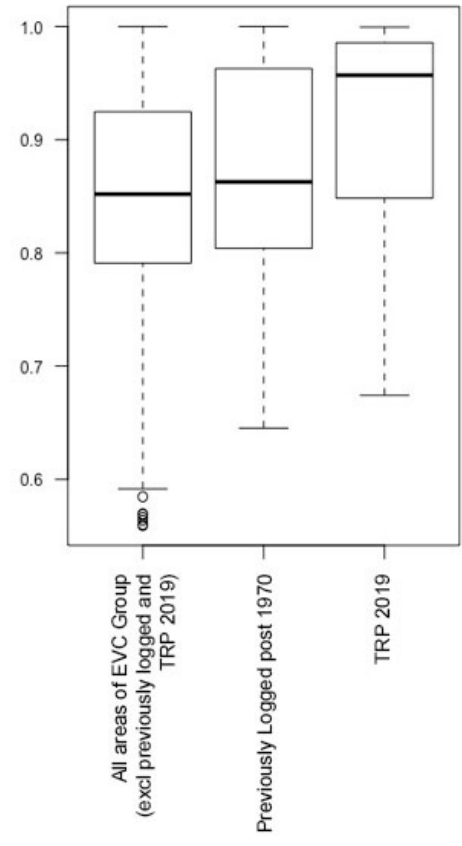

Wet and Damp EVC Group

Appendix S11. Log weight Zonation prioritisation scores for Dry Forest EVC Group (left), Mallee EVC Group (middle) and Wet or Damp Forest EVC Group (right) subject to clearfell logging 
Appendix S12. List of forest dependent threatened species modelled in this study

\begin{tabular}{|c|c|c|c|c|c|c|}
\hline Common name & Scientific name & Broad & Focus & EPBC & Vic Stat & FFG \\
\hline Spot-tailed Quoll & Dasyurus maculatus & $\bullet$ & $\bullet$ & $\mathrm{E}$ & $E$ & $\mathrm{~L}$ \\
\hline Brush-tailed Phascogale & Phascogale tapoatafa & $\bullet$ & & & V & $\mathrm{L}$ \\
\hline Swamp Antechinus & Antechinus minimus & $\bullet$ & & V & NT & $\mathrm{L}$ \\
\hline White-footed Dunnart & Sminthopsis leucopus & $\bullet$ & & & NT & $\mathrm{L}$ \\
\hline Greater Glider & Petauroides volans & $\bullet$ & $\bullet$ & V & V & \\
\hline Squirrel Glider & Petaurus norfolcensis & $\bullet$ & & & $E$ & $\mathrm{~L}$ \\
\hline Yellow-bellied Glider & Petaurus australis & & $\bullet$ & & & \\
\hline Leadbeater's Possum & Gymnobelideus leadbeateri & - & $\bullet$ & CE & $E$ & $\mathrm{~L}$ \\
\hline Long-nosed Potoroo & Potorous tridactylus & $\bullet$ & & $\mathrm{V}$ & NT & $\mathrm{L}$ \\
\hline Long-footed Potoroo & Potorous longipes & $\bullet$ & $\bullet$ & $E$ & V & $\mathrm{L}$ \\
\hline Brush-tailed Rock Wallaby & Petrogale penicillata & $\bullet$ & & V & CE & $\mathrm{L}$ \\
\hline Grey-headed Flying-fox & Pteropus poliocephalus & - & & $\mathrm{V}$ & V & $\mathrm{L}$ \\
\hline Eastern Horseshoe Bat & Rhinolopus megaphyllus & $\bullet$ & & & V & $\mathrm{L}$ \\
\hline Yellow-bellied Sheathtail Bat & Saccolaimus flaviventris & - & & & DD & $\mathrm{L}$ \\
\hline Smoky Mouse & Pseudomys fumeus & $\bullet$ & & $E$ & $E$ & $\mathrm{~L}$ \\
\hline Broad-toothed Rat & Mastacomys fuscus & $\bullet$ & & V & $E$ & $\mathrm{~L}$ \\
\hline Square-tailed Kite & Lophoictinia isura & $\bullet$ & & & V & $\mathrm{L}$ \\
\hline White-bellied Sea-eagle & Haliaeetus leucogaster & • & & & V & $\mathrm{L}$ \\
\hline Grey Goshawk & Accipiter novaehollandiae & $\bullet$ & & & V & $\mathrm{L}$ \\
\hline Glossy Black-Cockatoo & Calyptorhynchus lathami & $\bullet$ & $\bullet$ & & V & $\mathrm{L}$ \\
\hline Swift Parrot & Lathamus discolor & - & & CE & $E$ & $\mathrm{~L}$ \\
\hline Turquoise Parrot & Neophema pulchella & $\bullet$ & & & NT & $\mathrm{L}$ \\
\hline Powerful Owl & Ninox strenua & $\bullet$ & $\bullet$ & & $\mathrm{V}$ & $\mathrm{L}$ \\
\hline Barking Owl & Ninox connivens & - & & & $E$ & $\mathrm{~L}$ \\
\hline Sooty Owl & Tyto tenebricosa & • & $\bullet$ & & V & $\mathrm{L}$ \\
\hline Masked Owl & Tyto novaehollandiae & • & $\bullet$ & & $E$ & $\mathrm{~L}$ \\
\hline Brown Treecreeper & Climacteris picumnus victoriae & - & & & NT & \\
\hline Chestnut-rumped Heathwren & Calamanthus pyrrhopygius & - & & & $\mathrm{V}$ & $\mathrm{L}$ \\
\hline Speckled Warbler & Chthonicola sagittate & $\bullet$ & & & V & $\mathrm{L}$ \\
\hline Regent Honeyeater & Anthochaera Phrygia & • & & CE & CE & $\mathrm{L}$ \\
\hline Helmeted Honeyeater & Lichenostomus melanops cassidix & $\bullet$ & & CE & CE & $\mathrm{L}$ \\
\hline Hooded Robin & Melanodryas cucullate & • & & & BT & $\mathrm{L}$ \\
\hline Giant Burrowing Frog & Heleioporus australiacus & - & & V & V & $\mathrm{L}$ \\
\hline Baw Baw Frog & Philoria frosti & $\bullet$ & & $E$ & CE & $\mathrm{L}$ \\
\hline Brown Toadlet & Pseudophryne bibronii & $\bullet$ & & & $E$ & $\mathrm{~L}$ \\
\hline Southern Toadlet & Pseudophryne semimarmorata & $\bullet$ & & & V & \\
\hline Martin's Toadlet & Uperoleia martini & $\bullet$ & & & $E$ & $\mathrm{~L}$ \\
\hline Green and Golden Bell Frog & Litoria aurea & $\bullet$ & & V & V & $\mathrm{L}$ \\
\hline Booroolong Tree Frog & Litoria booroolongensis & $\bullet$ & & $E$ & CE & $\mathrm{L}$ \\
\hline Large Brown Tree Frog & Litoria littlejohni & • & & $\mathrm{V}$ & $E$ & $\mathrm{~L}$ \\
\hline Spotted Tree Frog & Litoria spenceri & $\bullet$ & & $E$ & $E$ & $\mathrm{~L}$ \\
\hline Rosenberg's Goanna & Varanus rosenbergi & $\bullet$ & & & $E$ & L \\
\hline Lace Monitor & Varanus varius & - & & & $E$ & \\
\hline Eastern She-oak Skink & Cyclodomorphus michaeli & $\bullet$ & & & NT & $\mathrm{L}$ \\
\hline Swamp Skink & Egernia coventryi & $\bullet$ & & & $E$ & $\mathrm{~L}$ \\
\hline Alpine Bog Skink & Pseudemoia cryodroma & $\bullet$ & & & V & $\mathrm{L}$ \\
\hline
\end{tabular}


Flat-headed Galaxias

Barred Galaxias

Dwarf Galaxias

Australian Grayling

Murray Cod

Trout Cod

Macquarie Perch

Empire Gudgeon

Cox's Gudgeon

Orbost Spiny Cray

Tall Astelia

Elegant Daisy

Forest Sedge

Blackfellow's Hemp

Gippsland Stringybark

Gully Grevillea

Colquhoun Grevillea

Outcrop Guinea-flower

Oval-leaf Grevillea

Brown Guinea-flower

Toothed Leionema

Tree Geebung

Smooth Geebung

Forest Geebung

Velvety Geebung

Forest Phebalium

Tasmanian Wax-flower

Veined Pomaderris

Eastern Pomaderris

Upright Pomaderris

Serpent Heath

Leafless Pink-bells

Slender Fork-fern

Oval Fork-fern

Small Fork-fern

Baw Baw Berry

Sandfly Zieria
Galaxias rostratus

Galaxias fuscus

Galaxiella pusilla

Prototroctes maraena

Maccullochella peelii

Maccullochella macquariensis

Macquaria australasica

Hypseleotris compressa

Gobiomorphus coxii

Euastacus diversus

Astelia australiana

Brachyscome salkiniae

Carex alsophila

Commersonia rossii

Eucalyptus mackintii

Grevillea barklyana

Grevillea celata

Hibbertia hermanniifolia

Grevillea miqueliana

Hibbertia rufa

Leionema bilobum

Persoonia arborea

Persoonia levis

Persoonia sylvatica

Persoonia subvelutina

Phebalium squamulosum

squamulosum

Philotheca virgata

Pomaderris costata

Pomaderris discolor

Pomaderris virgate

Richea Victoriana

Leafless Pink-bells

Tmesipteris elongate

Tmesipteris ovata

Tmesipteris parva

Wittsteinia vacciniacea

Zieria smithii smithii

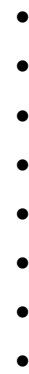

$\bullet$

•

$\bullet$

-

E

V

V

$\mathrm{R}$

$\mathrm{R}$

V

$\mathrm{R}$

$\mathrm{V}$

L

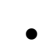

$\bullet$

- $\mathrm{P}$

- $\bullet \quad \mathrm{R}$

- $\bullet \quad \mathrm{R}$

- $\bullet \quad \mathrm{V}$

- $\bullet \quad \mathrm{R}$

- $\bullet \quad \mathrm{R}$

- $-\mathrm{R}$

- $\quad \mathrm{R}$

- $-\mathrm{V}$

- $\quad$ R

- $\bullet \quad \mathrm{R}$

• V

• R

- $\bullet \quad \mathrm{R}$

$\bullet \quad \mathrm{V}$

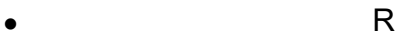

- $\mathrm{R}$

$\bullet \quad \bullet \quad \mathrm{R}$

$\mathrm{R}$

Key:

EPBC: National conservation status under the Commonwealth Environment Protection and Biodiversity Conservation Act 1999

$\mathrm{CE}=$ Critically Endangered

$\mathrm{E}=$ Endangered

$\mathrm{V}=$ Vulnerable

Vic Stat: Conservation status in Victoria

$\mathrm{CE}=$ Critically Endangered

$\mathrm{E}=$ Endangered

$\mathrm{V}=$ Vulnerable

$\mathrm{R}=$ Rare

$\mathrm{DD}=$ Data deficient

$\mathrm{P}=$ Parent (a species with all its subspecies listed as threatened: Grevillea miqueliana cincta is endangered, G. m. miqueliana and G. m. moroka are vulnerable).

FFG: $\quad \mathrm{L}=$ listed as a threatened taxon under the Victorian Flora and Fauna Guarantee Act 1988. 
Appendix S13. The area of forest and woodland EVC Groups (excl. wetlands) derived from EVC Group dataset (DSE 2005)

\begin{tabular}{lcc}
\hline Description & Area (ha) & \% of Total \\
\hline Box Ironbark and lower fertility forests & 359,598 & $3 \%$ \\
Coastal Scrub & 47,814 & $0 \%$ \\
Dry Forest & $2,704,455$ & $26 \%$ \\
Heathland & 293,356 & $3 \%$ \\
Heathy Woodland & 329,216 & $3 \%$ \\
Herb Rich Woodland & 170,834 & $2 \%$ \\
Lower Slope Woodlands & 395,956 & $4 \%$ \\
Lowland Forests & 598,168 & $6 \%$ \\
Mallee & $1,541,988$ & $15 \%$ \\
Montane Grasslands & 389,979 & $4 \%$ \\
Plains Grasslands & 240,562 & $2 \%$ \\
Plains Woodland & 859,150 & $8 \%$ \\
Rainforests & 36,856 & $0 \%$ \\
Riparian & 275,426 & $3 \%$ \\
Riverine Grassy Woodland & 395,956 & $4 \%$ \\
Rocky Outcrop & 81,682 & $1 \%$ \\
Salt Tolerant Vegetation & 93,137 & $1 \%$ \\
Sub-alpine Woodland & 116,048 & $1 \%$ \\
Wet and Damp Forests & $1,350,734$ & $13 \%$ \\
Total & $10,280,915$ & $100 \%$ \\
\hline
\end{tabular}

Appendix S14. Tukey's HSD test for equal weight Zonation results between ACLUMP derived land use categories and areas allocated to logging. Bold text denotes statistically significance $\mathrm{P}<0.05$.

\begin{tabular}{lcccc}
\hline Sequence & diff & Iwr & upr & p adj \\
\hline Informal Protected Area-Dedicated Reserve & $\mathbf{0 . 1 9 1}$ & $\mathbf{0 . 1 7 3}$ & $\mathbf{0 . 2 0 8}$ & $\mathbf{0 . 0 0 0}$ \\
Logging Permitted-Dedicated Reserve & $\mathbf{0 . 2 2 4}$ & $\mathbf{0 . 2 1 0}$ & $\mathbf{0 . 2 3 9}$ & $\mathbf{0 . 0 0 0}$ \\
Other Parks-Dedicated Reserve & -0.109 & -0.232 & 0.015 & 0.122 \\
Other State Forest-Dedicated Reserve & $-\mathbf{0 . 1 3 3}$ & $-\mathbf{0 . 1 6 1}$ & $-\mathbf{0 . 1 0 6}$ & $\mathbf{0 . 0 0 0}$ \\
Private Land-Dedicated Reserve & 0.002 & -0.014 & 0.019 & 0.998 \\
Logging Permitted-Informal Protected Area & $\mathbf{0 . 0 3 4}$ & $\mathbf{0 . 0 1 4}$ & $\mathbf{0 . 0 5 3}$ & $\mathbf{0 . 0 0 0}$ \\
Other Parks-Informal Protected Area & $\mathbf{- 0 . 2 9 9}$ & $-\mathbf{0 . 4 2 4}$ & $\mathbf{- 0 . 1 7 5}$ & $\mathbf{0 . 0 0 0}$ \\
Other State Forest-Informal Protected Area & $\mathbf{- 0 . 3 2 4}$ & $\mathbf{- 0 . 3 5 5}$ & $\mathbf{- 0 . 2 9 3}$ & $\mathbf{0 . 0 0 0}$ \\
Private Land-Informal Protected Area & $\mathbf{- 0 . 1 8 8}$ & $\mathbf{- 0 . 2 1 0}$ & $\mathbf{- 0 . 1 6 7}$ & $\mathbf{0 . 0 0 0}$ \\
Other Parks-Logging Permitted & $-\mathbf{0 . 3 3 3}$ & $-\mathbf{0 . 4 5 7}$ & $\mathbf{- 0 . 2 0 9}$ & $\mathbf{0 . 0 0 0}$ \\
Other State Forest-Logging Permitted & $\mathbf{- 0 . 3 5 8}$ & $-\mathbf{0 . 3 8 7}$ & $\mathbf{- 0 . 3 2 9}$ & $\mathbf{0 . 0 0 0}$ \\
Private Land-Logging Permitted & $-\mathbf{0 . 2 2 2}$ & $-\mathbf{0 . 2 4 1}$ & $\mathbf{- 0 . 2 0 3}$ & $\mathbf{0 . 0 0 0}$ \\
Other State Forest-Other Parks & -0.025 & -0.151 & 0.101 & 0.994 \\
Private Land-Other Parks & 0.111 & -0.013 & 0.235 & 0.110 \\
Private Land-Other State Forest & $\mathbf{0 . 1 3 6}$ & $\mathbf{0 . 1 0 5}$ & $\mathbf{0 . 1 6 6}$ & $\mathbf{0 . 0 0 0}$ \\
\hline
\end{tabular}


Appendix S15. Tukey's HSD test for linear weight Zonation results between ACLUMP derived land use categories and areas allocated to logging. Bold text denotes statistically significance $\mathrm{P}<0.05$.

\begin{tabular}{lcccc}
\hline Sequence & diff & Iwr & upr & $p$ adj \\
\hline Informal Protected Area-Dedicated Reserve & 0.186 & 0.169 & 0.204 & 0.000 \\
Logging Permitted-Dedicated Reserve & 0.213 & 0.199 & 0.227 & 0.000 \\
Other Parks-Dedicated Reserve & -0.150 & -0.272 & -0.027 & 0.007 \\
Other State Forest-Dedicated Reserve & -0.125 & -0.153 & -0.097 & 0.000 \\
Private Land-Dedicated Reserve & 0.001 & -0.016 & 0.017 & 1.000 \\
Logging Permitted-Informal Protected Area & 0.027 & $\mathbf{0 . 0 0 7}$ & $\mathbf{0 . 0 4 6}$ & $\mathbf{0 . 0 0 1}$ \\
Other Parks-Informal Protected Area & -0.336 & -0.459 & -0.212 & 0.000 \\
Other State Forest-Informal Protected Area & -0.311 & -0.342 & -0.281 & 0.000 \\
Private Land-Informal Protected Area & -0.185 & -0.207 & -0.164 & 0.000 \\
Other Parks-Logging Permitted & -0.363 & -0.486 & -0.240 & 0.000 \\
Other State Forest-Logging Permitted & -0.338 & -0.367 & -0.309 & 0.000 \\
Private Land-Logging Permitted & -0.212 & -0.231 & -0.193 & 0.000 \\
Other State Forest-Other Parks & 0.024 & -0.101 & 0.150 & 0.994 \\
Private Land-Other Parks & 0.150 & $\mathbf{0 . 0 2 7}$ & $\mathbf{0 . 2 7 4}$ & $\mathbf{0 . 0 0 7}$ \\
Private Land-Other State Forest & $\mathbf{0 . 1 2 6}$ & $\mathbf{0 . 0 9 6}$ & $\mathbf{0 . 1 5 6}$ & $\mathbf{0 . 0 0 0}$ \\
\hline
\end{tabular}

Appendix S16. Tukey's HSD test for log weight Zonation results between ACLUMP derived land use categories and areas allocated to logging. Bold text denotes statistically significance $\mathrm{P}<0.05$.

\begin{tabular}{lcccc}
\hline Sequence & diff & Iwr & upr & p adj \\
\hline Informal Protected Area-Dedicated Reserve & $\mathbf{0 . 2 1 7}$ & $\mathbf{0 . 1 9 9}$ & $\mathbf{0 . 2 3 4}$ & $\mathbf{0 . 0 0 0}$ \\
Logging Permitted-Dedicated Reserve & $\mathbf{0 . 2 2 7}$ & $\mathbf{0 . 2 1 2}$ & $\mathbf{0 . 2 4 1}$ & $\mathbf{0 . 0 0 0}$ \\
Other Parks-Dedicated Reserve & $-\mathbf{0 . 2 0 8}$ & $-\mathbf{0 . 3 3 0}$ & $\mathbf{- 0 . 0 8 6}$ & $\mathbf{0 . 0 0 0}$ \\
Other State Forest-Dedicated Reserve & $-\mathbf{0 . 1 5 1}$ & $-\mathbf{0 . 1 7 8}$ & $-\mathbf{0 . 1 2 3}$ & $\mathbf{0 . 0 0 0}$ \\
Private Land-Dedicated Reserve & -0.006 & -0.023 & 0.010 & 0.897 \\
Logging Permitted-Informal Protected Area & 0.010 & -0.009 & 0.030 & 0.661 \\
Other Parks-Informal Protected Area & $-\mathbf{0 . 4 2 4}$ & $-\mathbf{0 . 5 4 7}$ & $-\mathbf{0 . 3 0 1}$ & $\mathbf{0 . 0 0 0}$ \\
Other State Forest-Informal Protected Area & $-\mathbf{0 . 3 6 7}$ & $-\mathbf{0 . 3 9 8}$ & $\mathbf{- 0 . 3 3 7}$ & $\mathbf{0 . 0 0 0}$ \\
Private Land-Informal Protected Area & $-\mathbf{0 . 2 2 3}$ & $-\mathbf{0 . 2 4 4}$ & $-\mathbf{0 . 2 0 2}$ & $\mathbf{0 . 0 0 0}$ \\
Other Parks-Logging Permitted & $-\mathbf{0 . 4 3 4}$ & $-\mathbf{- 0 . 5 5 7}$ & $-\mathbf{0 . 3 1 2}$ & $\mathbf{0 . 0 0 0}$ \\
Other State Forest-Logging Permitted & $-\mathbf{0 . 3 7 8}$ & $-\mathbf{0 . 4 0 6}$ & $\mathbf{- 0 . 3 4 9}$ & $\mathbf{0 . 0 0 0}$ \\
Private Land-Logging Permitted & $-\mathbf{0 . 2 3 3}$ & $\mathbf{- 0 . 2 5 2}$ & $\mathbf{- 0 . 2 1 4}$ & $\mathbf{0 . 0 0 0}$ \\
Other State Forest-Other Parks & 0.057 & -0.068 & 0.181 & 0.785 \\
Private Land-Other Parks & $\mathbf{0 . 2 0 2}$ & $\mathbf{0 . 0 7 9}$ & $\mathbf{0 . 3 2 4}$ & $\mathbf{0 . 0 0 0}$ \\
Private Land-Other State Forest & $\mathbf{0 . 1 4 5}$ & $\mathbf{0 . 1 1 5}$ & $\mathbf{0 . 1 7 5}$ & $\mathbf{0 . 0 0 0}$ \\
\hline
\end{tabular}


Appendix S17. Tukey's HSD test for all weight Zonation results between areas previously clearfell logged post 1970, areas scheduled for clearfell logging under the 2019 Timber Release Plan and remaining forest area not logged. Bold text denotes statistically significance $\mathrm{P}<0.05$.

\begin{tabular}{|c|c|c|c|c|c|}
\hline Equal & Sequence & Diff & Lower & Upper & $P$ adj \\
\hline Wet and Damp Forest & Previously Logged post 1970-Remaining EVC Group Areas & 0.044 & 0.029 & 0.058 & 0.000 \\
\hline Wet and Damp Forest & TRP 2019- Remaining EVC Group Areas & 0.057 & 0.030 & 0.083 & 0.000 \\
\hline Wet and Damp Forest & TRP 2019-Previously Logged post 1970 & 0.013 & -0.016 & 0.042 & 0.546 \\
\hline Dry Forest & Previously Logged post 1970 - Remaining EVC Group Areas & 0.079 & 0.045 & 0.113 & 0.000 \\
\hline Dry Forest & TRP 2019- Remaining EVC Group Areas & 0.108 & 0.034 & 0.182 & 0.002 \\
\hline Dry Forest & TRP 2019-Previously Logged post 1970 & 0.029 & -0.052 & 0.109 & 0.685 \\
\hline All Forests & Previously Logged post 1970- Remaining EVC Group Areas & 0.246 & 0.218 & 0.274 & 0.000 \\
\hline All Forests & TRP 2019- Remaining EVC Group Areas & 0.256 & 0.199 & 0.312 & 0.000 \\
\hline All Forests & TRP 2019-Previously Logged post 1970 & 0.010 & -0.053 & 0.073 & 0.925 \\
\hline Linear & Sequence & Diff & Lower & Upper & $P$ adj \\
\hline Wet and Damp Forest & Previously Logged post 1970-Remaining EVC Group Areas & 0.035 & 0.021 & 0.049 & 0.000 \\
\hline Wet and Damp Forest & TRP 2019- Remaining EVC Group Areas & 0.061 & 0.035 & 0.087 & 0.000 \\
\hline Wet and Damp Forest & TRP 2019-Previously Logged post 1970 & 0.026 & -0.003 & 0.054 & 0.094 \\
\hline Dry Forest & Previously Logged post 1970- Remaining EVC Group Areas & 0.049 & 0.019 & 0.079 & 0.000 \\
\hline Dry Forest & TRP 2019- Remaining EVC Group Areas & 0.094 & 0.029 & 0.159 & 0.002 \\
\hline Dry Forest & TRP 2019-Previously Logged post 1970 & 0.045 & -0.026 & 0.117 & 0.294 \\
\hline All Forests & Previously Logged post 1970- Remaining EVC Group Areas & 0.221 & 0.193 & 0.249 & 0.000 \\
\hline All Forests & TRP 2019- Remaining EVC Group Areas & 0.244 & 0.188 & 0.300 & 0.000 \\
\hline All Forests & TRP 2019-Previously Logged post 1970 & 0.024 & -0.038 & 0.086 & 0.646 \\
\hline $\log$ & Sequence & Diff & Lower & Upper & $P$ adj \\
\hline Wet and Damp Forest & Previously Logged post 1970-Remaining EVC Group Areas & 0.020 & 0.008 & 0.031 & 0.000 \\
\hline Wet and Damp Forest & TRP 2019-Remaining EVC Group Areas & 0.066 & 0.045 & 0.088 & 0.000 \\
\hline Wet and Damp Forest & TRP 2019-Previously Logged post 1970 & 0.047 & 0.023 & 0.070 & 0.000 \\
\hline Dry Forest & Previously Logged post 1970-Remaining EVC Group Areas & -0.048 & -0.073 & -0.023 & 0.000 \\
\hline Dry Forest & TRP 2019-Remaining EVC Group Areas & 0.035 & -0.018 & 0.088 & 0.276 \\
\hline Dry Forest & TRP 2019-Previously Logged post 1970 & 0.083 & 0.024 & 0.141 & 0.003 \\
\hline All Forests & Previously Logged post 1970-Remaining EVC Group Areas & 0.184 & 0.156 & 0.212 & 0.000 \\
\hline All Forests & TRP 2019-Remaining EVC Group Areas & 0.235 & 0.178 & 0.291 & 0.000 \\
\hline All Forests & TRP 2019-Previously Logged post 1970 & 0.051 & -0.012 & 0.114 & 0.141 \\
\hline
\end{tabular}


Appendix S18. Area Analysis of the top scoring 10 percent for the equal, linear and log weight Zonation

\begin{tabular}{lrrrrrr}
\hline Land Tenure & $\begin{array}{c}\text { Area Equal } \\
\text { Weight (ha) }\end{array}$ & $\begin{array}{c}\text { \% of Total } \\
\text { Equal } \\
\text { Weight }\end{array}$ & $\begin{array}{c}\text { Area Linear } \\
\text { Weight (ha) }\end{array}$ & $\begin{array}{c}\text { \% of Total } \\
\text { Equal } \\
\text { Weight }\end{array}$ & $\begin{array}{c}\text { Area Log } \\
\text { Weight (ha) }\end{array}$ & $\begin{array}{c}\text { \% of Total } \\
\text { Equal } \\
\text { Weight }\end{array}$ \\
\hline Dedicated Reserves & 907,329 & $44 \%$ & 937,615 & $46 \%$ & 865,018 & $42 \%$ \\
Informal Protection & 275,295 & $13 \%$ & 246,369 & $12 \%$ & 286,977 & $14 \%$ \\
Logging Permitted & 597,590 & $29 \%$ & 500,841 & $24 \%$ & 532,241 & $26 \%$ \\
Other Parks & 1,208 & $0 \%$ & 1,207 & $0 \%$ & 968 & $0 \%$ \\
Other State Forests & 42,119 & $2 \%$ & 47,958 & $2 \%$ & 20,761 & $1 \%$ \\
Private Land & 244,341 & $12 \%$ & 303,647 & $15 \%$ & 318,545 & $16 \%$ \\
Other Land Use & 17,024 & $1 \%$ & 18,824 & $1 \%$ & 12,051 & $1 \%$ \\
Total & $\mathbf{2 , 0 8 4 , 9 0 7}$ & $\mathbf{1 0 0} \%$ & $\mathbf{2 , 0 5 6 , 4 6 0}$ & $\mathbf{1 0 0 \%}$ & $\mathbf{2 , 0 3 6 , 5 6 2}$ & $\mathbf{1 0 0 \%}$ \\
\hline
\end{tabular}

